
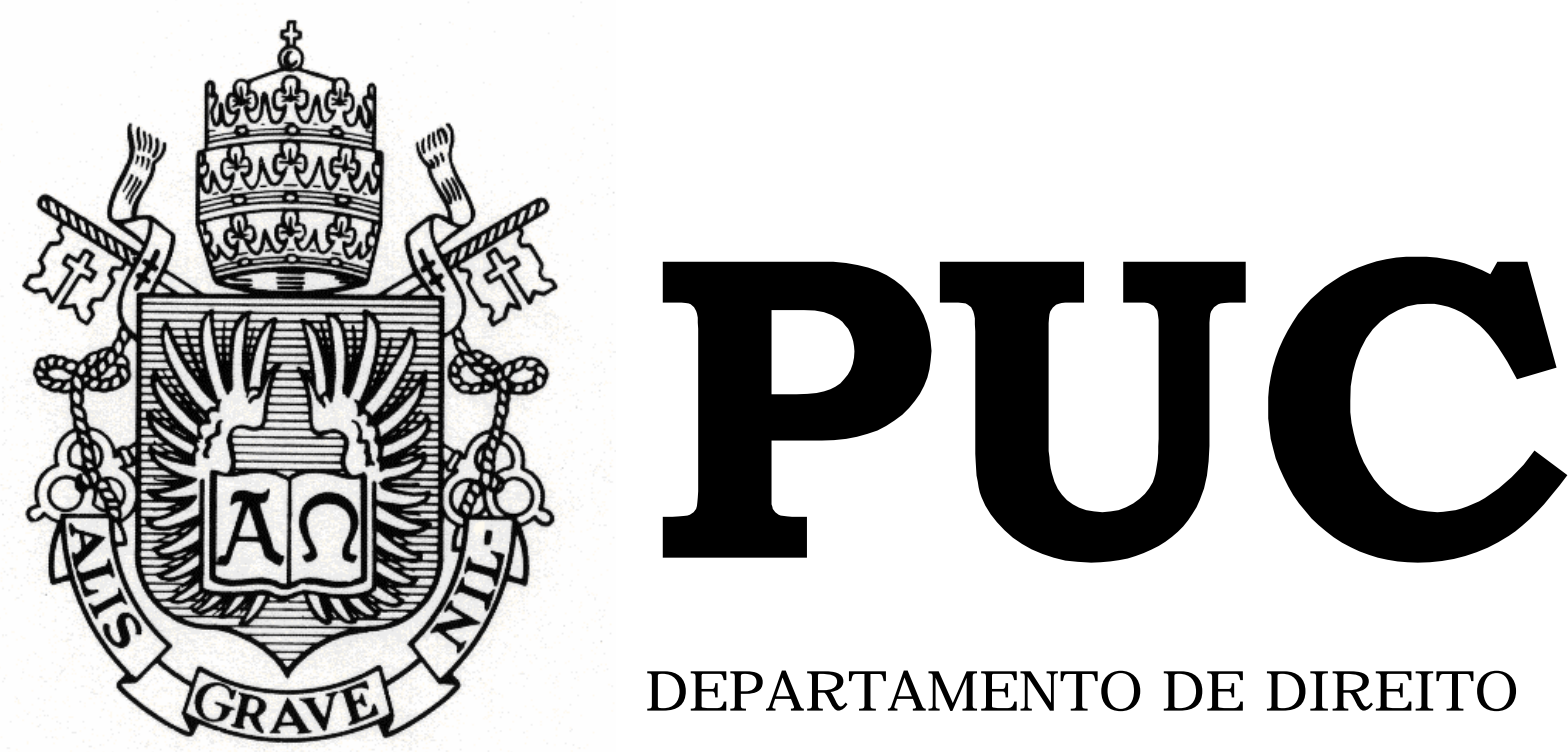

DEPARTAMENTO DE DIREITO

\title{
O INGRESSO DOS TRATADOS INTERNACIONAIS NO ORDENAMENTO JURÍDICO BRASILEIRO: A PRISÃO CIVIL DO DEPOSITÁRIO INFIEL E A CONSTITUCIONALIDADE DO PACTO DE SAN JOSÉ DA COSTA RICA
}

\author{
por \\ LIVIA RIBEIRO VERONESI MARINHO
}

ORIENTADOR(A): Daniela Vargas

2008.1 


\section{O INGRESSO DOS TRATADOS INTERNACIONAIS NO ORDENAMENTO JURÍDICO BRASILEIRO: A PRISÃO CIVIL DO DEPOSITÁRIO INFIEL E A CONSTITUCIONALIDADE DO PACTO DE SAN JOSÉ DA COSTA RICA}

por

LIVIA RIBEIRO VERONESI MARINHO

Monografia apresentada ao Departamento de Direito da Pontifícia Universidade Católica do Rio de Janeiro (PUC-Rio) para a obtenção do Título de Bacharel em Direito.

Orientador(a): Daniela Vargas 
Para Mara Lucia e José Carlos, meus pais queridos, com muito amor. 


\section{Agradecimentos}

Gostaria de agradecer aos meus pais, Mara Lúcia e José Carlos, por me amarem incondicionalmente, aos meus irmãos, Carolina e Pedro, por me ensinarem a dividir e a lutar pelas minhas coisas quando preciso, à minha Vó querida, Maria da Penha, por ser tão especial. Obrigada também às minhas amigas de faculdade, Paula, Monique, Sabrina e Camila, que me dão apoio há quatro anos e tornam as aulas muito mais divertidas.

Agradeço, ainda, à minha orientadora, Daniela Vargas. 
"Existe uma cidadania internacional que tem seus direitos, seus deveres e que se empenha em erguer-se contra todos os abusos do poder, qualquer que seja seu autor, quaisquer quer sejam as vítimas. Afinal de contas, somos todos governados e, a este título, solidários". Michel Foucault 


\section{Resumo}

O presente trabalho tem como objetivo fazer um levantamento das posições doutrinárias e jurisprudenciais acerca da problemática envolvendo o conflito entre o Pacto de San José da Costa Rica, mais especificamente o seu artigo $7^{\circ}$, inciso 7 , e a legislação brasileira, no que diz respeito a prisão civil do depositário infiel, bem como a dos devedores a ele equiparados legalmente. Inicialmente será feita uma análise das teorias de diversos doutrinadores de peso no pensamento jurídico brasileiro visando estabelecer a forma de ingresso dos tratados internacionais no ordenamento jurídico brasileiro, bem como o patamar hierárquico por eles ocupados. Além disso, iremos verificar de que forma as mudanças nas legislações brasileiras influenciam nestas abordagens doutrinárias. Será feita, ainda, uma pesquisa de decisões do Supremo Tribunal Federal e do Superior Tribunal de Justiça para se verificar como o conflito de normas envolvendo a prisão do depositário infiel vem sendo resolvido na prática.

São palavras-chave desta monografia: tratado internacional; direitos humanos; prisão civil; depositário infiel; Pacto de San José da Costa Rica. 


\section{Sumário}

Lista de abreviações ............................................................................. 7

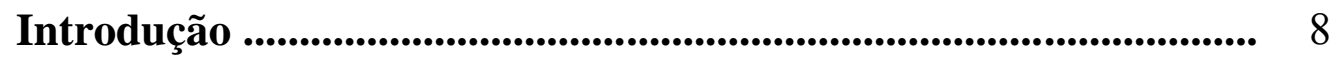

\section{Ingresso dos Tratados Internacionais no Ordenamento} Jurídico Brasileiro .................................................................................. 11

1.1 - As teorias dualista e monista _.......................................... 12

1.2 - Posição hierárquica ocupada pelos Tratados Internacionais no ordenamento jurídico brasileiro .................... 15

1.2.1 - O Pacto de San José da Costa Rica e os Códigos Civil de 1916 e de Processo Civil de 1973 ....................... 19

1.2.2 - O Pacto de San José da Costa Rica e o Código Civil de 2002

1.2.3 - O $\S 3^{\circ}$ do artigo $5^{\circ}$ da Constituição Federal incluído pela Emenda Constitucional n. ${ }^{\circ} 45 / 2004$

2. A possibilidade da prisão do depositário infiel e a constitucionalidade do Pacto de San José da Costa Rica ................ 26

2.1. O entendimento do Supremo Tribunal Federal ................. 29

2.2. O entendimento do Superior Tribunal de Justiça ............... 44

2.3. Comparação das posições jurisprudenciais do STF e do STJ

Conclusão 


\section{Lista de abreviações}

AC - Apelação Cível

AgR - Agravo Regimental

art. - artigo

arts. - artigos

CC - Código Civil

CCivil - Código Civil

CF - Constituição Federal

CPC - Código de Processo Civil

CR - Carta Rogatória

EC - Emenda Constitucional

Decr. - Decreto

$\mathrm{HC}$ - Habeas Corpus

n. ${ }^{\circ}$ - número

ONU - Organização das Nações Unidas

RE - Recurso Extraordinário

REsp - Recurso Especial

RHC - Recurso Ordinário em Habeas Corpus

S.A. - Sociedade Anônima

STF - Supremo Tribunal Federal

STJ - Superior Tribunal de Justiça 


\section{Introdução}

O constante desenvolvimento da sociedade ao longo da história produz diversos reflexos no Direito. No atual nível de globalização, é possível observar que ações praticadas por um Estado, tanto no âmbito interno como no externo, podem repercutir no cenário internacional, já que diversos problemas transcendem fronteiras nacionais. Neste contexto, o desenvolvimento acelerado do Direito Internacional é assunto de grande relevo.

O Estado deve estar voltado para uma cooperação internacional e não fechado para si mesmo e a ratificação de tratados internacionais mostra um avanço para um sistema mais integrado, fundado nas relações envolvendo os sujeitos de Direito Internacional. Soma-se a isso o fato de que a adesão a estes instrumentos jurídicos representa um ponto positivo na busca de legitimidade e credibilidade no plano externo, servindo de referência para outros Estados na comunidade internacional.

Neste sentido, o presente trabalho tem como objetivo abordar o ingresso do tratados internacionais no Direito Interno e o patamar hierárquico ocupados por eles no ordenamento jurídico brasileiro. Trataremos, mais especificamente, do Pacto de San José da Costa Rica (Convenção Americana sobre Direitos Humanos), bem como sua aplicabilidade frente as normas pátrias, e da prisão do depositário infiel.

O tema abordado não é pacífico. Ele tem sido fruto de discussões tanto na doutrina como na jurisprudência. Desta forma, esta pesquisa tem como propósito fazer um levantamento das teorias utilizadas para a solução dos conflitos entre Direito Internacional e Direito Interno, questão abordada por grandes doutrinadores e que é objeto de vários julgados nos tribunais brasileiros e de casos ainda em tramitação.

Cabe analisar em quais hipóteses será aplicada a legislação internacional e quando esta será afastada, dando prioridade as normas de direito interno, voltando-se mais especificamente para a aplicação do Pacto 
de San José da Costa Rica, quando se trata da prisão civil do depositário infiel.

Como metodologia, serão observadas diversas teorias, sendo elas divergentes ou não, dos vários autores de peso no pensamento jurídico brasileiro. Em primeiro lugar, ensinamentos como os de Carlos Roberto Siqueira Castro, José Afonso da Silva André de Carvalho Ramos, Nadia de Araújo, Antônio Augusto Cançado Trindade apresentam suporte para se abordar o ingresso do tratados internacionais no Direito Interno e o patamar hierárquico ocupados por eles no ordenamento jurídico brasileiro. No âmbito da prisão do depositário infiel e do Pacto de San José da Costa Rica Inácio de Carvalho Neto, Valério de Oliveira Mazzuoli, Flávia Piovesan se mostram de grande importância no debate estabelecido.

Fará-se, ainda, referência a posições de Tribunais e magistrados brasileiros para que se possa entender melhor como o tema é abordado na prática e que soluções estão sendo dadas acerca destes conflitos envolvendo as normas de Direito Interno e o artigo $7^{\circ}$, inciso 7 do Pacto de San José da Costa Rica.

Além disso, será investigada a aplicação da legislação brasileira, tanto a Constituição Federal, como os Códigos Civis de 1916 e de 2002 e o de Processo Civil. Além disso, será analisado o Decreto-Lei 911/1969.

Para tal, a presente monografia tratará, em seu capítulo 1, do ingresso dos tratados internacionais no ordenamento jurídico brasileiro, passando pelas teorias monista e dualista que tratam do conflito entre normas do Direito Internacional e do Direito Interno. Analisaremos, ainda, a posição hierárquica ocupada por esse tratado no Direito pátrio, além do conflito entre o Pacto de San José da Costa Rica e a legislação brasileira, levando também em consideração as mudanças trazidas pelo Novo Código Civil e pela Emenda Constitucional n. ${ }^{\circ} 45 / 2004$ ao se tratar da prisão do depositário infiel.

Já no segundo capítulo, será analisadas a possibilidade da prisão civil do depositário infiel e a constitucionalidade do Pacto de San José da Costa 
Rica. Com a ratificação pelo Brasil deste tratado internacional 1992, se observa um grande debate envolvendo ele e o artigo $5^{\circ}$, LXVII da Constituição Federal, mais especificamente a prisão civil do depositário infiel, já que não há duvidas quanto a possibilidade da prisão civil do devedor de alimentos. Será feita uma pesquisa acerca das posições adotadas pelo Supremo Tribunal Federal e o Superior Tribunal de Justiça, bem como uma comparação entre as decisões de ambos tribunais ao longo do tempo.

Isto exposto, se busca uma teoria que se pareça a mais correta, devendo ser analisadas diversas posições e os argumentos em que elas se baseiam. 


\section{1 - Ingresso dos Tratados Internacionais no Ordenamento Jurídico Brasileiro}

A celebração e a ratificação dos tratados e seu ingresso no ordenamento jurídico brasileiro é fruto de um ato complexo que conjuga a vontade do Chefe do Poder Executivo e a do Congresso Nacional.

A Constituição Federal, em seu artigo 84, VIII, atribui competência privativa ao Presidente da República para celebrar tratados, convenções ou atos internacionais, ficando eles sujeitos ao referendo do Congresso Nacional. Já o artigo 49, I da CF, confere ao Congresso Nacional competência exclusiva para resolver definitivamente sobre tratados, acordos ou atos internacionais que acarretem encargos ou compromissos gravosos ao patrimônio nacional. Tendo sido aprovado o tratado, por Decreto Legislativo, cabe ainda a ratificação pelo Presidente da República.

Se os tratados e convenções internacionais são os contratos dos Estados, que têm por fim estabelecer entre estes relações obrigatórias, o certo é que os respectivos governos não se reconhecem obrigados por eles senão depois de terem ratificado. [...] Até o momento da ratificação, o que há é um tratado assinado, mas ainda não aprovado. Não basta, em verdade, que o firmem as partes contratantes. A assinatura, por si não lhe dá força obrigatória. Para tanto indispensável é a ratificação, ato solene pelo qual o Chefe de Estado o declara aceito. ${ }^{1}$

O tratado, porém, só passa a ter vigência dentro do território nacional após sua promulgação por decreto do Chefe do Poder Executivo e sua publicação. Cabe aqui ressaltar que a necessidade de promulgação dos tratados não se extrai do texto constitucional e sim, da Lei de Introdução do Código Civil, artigo $1^{\circ}$, que dispõe sobre a necessidade de publicação das leis para que passem a produzir efeitos combinado com o artigo 84, IV da Constituição Federal ${ }^{3}$.

\footnotetext{
1 TRINDADE, Antônio Augusto Cançado. Repertório da prática brasileira do direito internacional público (período de 1919-1940). Brasília: Escopo Editora, 1984. p. 85.

${ }^{2}$ Art. $1^{\circ}$ Salvo disposição contrária, a lei começa a vigorar em todo país 45 (quarenta e cinco) dias depois de oficialmente publicada.

${ }^{3}$ Art. 84. Compete privativamente ao Presidente da República:

IV - sancionar, promulgar e fazer publicar as leis, bem como expedir decretos e regulamentos para sua fiel execução.
} 
Após ter sido promulgado, se deve analisar que posição hierárquica a norma internacional ocupa no ordenamento jurídico brasileiro.

\section{1 - As teorias dualista e monista}

O conflito entre as normas de direito interno dos Estados e as normas dos Tratados Internacionais é um assunto que tem criado várias discussões na doutrina e na jurisprudência no mundo inteiro. Doutrinariamente, as posições adotadas se agrupam principalmente em duas linhas de pensamento: a teoria dualista e a teoria monista. Nestas teorias se debate a necessidade de um procedimento de internalização da norma internacional na ordem jurídica do Estado signatário e a posição hierárquica adquirida por esta norma dentro ordenamento.

A primeira delas, sustentada por Heinrich Triepel, defende que o Direito Internacional e o Direito Interno de cada Estado possuem objetivos próprios, havendo um sistema distinto para cada um desses ordenamentos, fundamentados em fontes jurídicas próprias. Desta forma, por serem ordenamentos jurídicos diferentes, não haveria, inicialmente, conflito entre as normas de Direito Internacional, que disciplinariam as relações entre os Estados, e de Direito Interno, que regulariam as relações entres sujeitos privados e entre estes e o próprio Estado.

Para que um tratado passasse a produzir efeitos na ordem do Estado signatário, seria necessária a criação de uma lei específica que determinasse sua incorporação. A norma internacional adquiriria status de norma estatal e, havendo divergência entre normas, a mais recente derrogaria a mais antiga (lex posteriores derogat legi prioli).

Observa-se que a principal preocupação dos dualistas é com o processo de internalização dos tratados, que não se daria de forma automática.

A teoria monista, defendida principalmente por Hans Kelsen, afirma que o Direito Internacional e o Interno formam um sistema único. O 
ordenamento jurídico seria um só, com desdobramentos internos e internacionais. Diferentemente dos dualistas, os monistas sustentam que os tratados não precisam passar por um processo de internalização para terem vigência na ordem interna. Sua incorporação seria de forma direta, já que não haveria divisão entre as normas oriundas do próprio Estado e aquelas provenientes de tratados e acordos internacionais.

Segundo os defensores desta vertente, havendo conflito entre as normas, ele poderia ser solucionado de três maneiras: com a prevalência do Direito interno sobre o internacional; com a primazia da norma internacional sobre a interna; ou, considerando as duas de mesmo patamar hierárquico, a mais recente deveria prevalecer sobre a mais antiga (monismo moderado) ${ }^{4}$.

A teoria monista tem seu foco, principalmente, na posição hierárquica que a norma internacional possuiria.

Observa-se que

para a corrente monista, $o$ ato de ratificação, por si só, irradiaria efeitos jurídicos no plano internacional e interno, concomitantemente - o tratado ratificado obrigaria nos planos internacional e interno. Para a corrente dualista, a ratificação só irradiaria efeitos no plano internacional, sendo necessário ato jurídico interno para que o tratado passe a irradiar efeitos no cenário interno. ${ }^{5}$

Ao abordarmos o tema enfocando o Direito Brasileiro, observa-se que não foi adotada especificamente qualquer dessas teorias. A Constituição Federal de 1988 é lacunosa no que diz respeito às relações entre o Direito Internacional e o Direito Interno.

A vigente Constituição brasileira, seguindo nossa tradição constituinte na matéria, e apartando-se do que preceituam alguns outros estatutos supremos mais antigos e de notório prestigio, não versa, direta e abrangentemente, a questão das relações entre o Direito Internacional e o Direito Interno. Ante a lacuna normativa supralegal, essa inevitável confrontação tem sido há tempos dirimida pela jurisprudência do Supremo Tribunal Federal e, já agora, com os suprimentos do Superior Tribunal de Justiça, no exercício das competências recursais estatuídas nos artigos 102, III, 'b', e 105, III, 'a', da nossa Lei Maior. ${ }^{6}$

\footnotetext{
${ }^{4}$ DOLINGER, Jacob. Direito Internacional Privado: parte geral. $4^{\mathrm{a}}$ ed. Rio de Janeiro: Renovar, 1996. p. 83

${ }^{5}$ PIOVESAN, Flávia. Valor Jurídico dos Tratados: Impacto na Ordem Interna e Internacional. Disponível em: http://www.mundojuridico.adv.br. Acesso em 30 de abril de 2008. p. 14.

${ }^{6}$ CASTRO, Carlos Roberto Siqueira. A Constituição aberta e os direitos fundamentais. Rio de Janeiro: Editora Forense, 2003. p. 145.
} 
Art. 102. Compete ao Supremo Tribunal Federal, precipuamente, a guarda da Constituição, cabendo-lhe:

III - julgar, mediante recurso extraordinário, as causas decididas em única ou última instância, quando a decisão recorrida:

b) declarar a inconstitucionalidade de tratado ou lei federal;

Art. 105. Compete ao Superior Tribunal de Justiça:

III - julgar, em recurso especial, as causa decididas, em única ou última instância, pelos Tribunais Regionais Federais ou pelos Tribunais dos Estados, do Distrito Federal e Territórios, quando a decisão recorrida:

a) contrariar tratado ou lei federal, ou negar-lhes vigência.

As duas teorias são usadas para fundamentar decisões em diversos tribunais, o que mostra que o assunto não é pacifico.

Parte da doutrina e da jurisprudência tem defendido que o Supremo Tribunal Federal teria se filiado a um monismo moderado ${ }^{7}$, como se observa no RE n. ${ }^{\circ}$ 80.004/SE, de 01 de junho de 1977. Este julgado foi "leading case", até $1995^{8}$, do Supremo Tribunal Federal sobre o conflito envolvendo Direito Internacional e Direito Interno. Trata-se de um conflito envolvendo a Lei Uniforme de Genebra, que entrou em vigor em 1966, e uma lei interna, o Decreto-Lei 427/69. Prevaleceu ao entendimento de que os tratados internacionais possuíam status de lei ordinária, aplicado-se a regra "lex posterior derrogat legi priori".

RE 80004 / SE - SERGIPE

Relator: Ministro Xavier de Albuquerque

Data do julgamento: $01 / 06 / 1977$

Órgão julgador: Tribunal Pleno

\section{EMENTA}

Convenção de Genebra, Lei Uniforme sobre Letras de Câmbio e Notas Promissórias, aval aposto a nota promissória não registrada no prazo legal, impossibilidade de ser o avalista acionado, mesmo pelas vias ordinárias. Validade do decreto-lei n. 427, de 22.01.1969. Embora a Convenção de Genebra que previu uma Lei Uniforme sobre Letras de Câmbio e Notas Promissórias tenha aplicabilidade no direito interno brasileiro, não se sobrepõe ela as leis do país, disso decorrendo a constitucionalidade e conseqüente validade do Dec. Lei ${ }^{\circ}$ 427/69, que institui o registro obrigatório da nota promissória em repartição fazendária, sob pena de nulidade do título. Sendo o aval um instituto do direito cambiário, inexistente será ele se reconhecida a nulidade do título cambial a que foi aposto. Recurso extraordinário conhecido e provido.

\footnotetext{
${ }^{7}$ DOLINGER, Jacob. Direito Internacional Privado: parte geral. $4^{\mathrm{a}}$ ed. Rio de Janeiro: Renovar, 1996. p. 99.

${ }^{8}$ Esse julgado foi "leading case" até o julgamento do HC 72.131/RJ, em 22 de novembro de 1995, quando o Plenário voltou a discutir a matéria, tendo agora como ponto principal o conflito entre as normas internas e as internacionais envolvendo a prisão do depositário infiel. Voltaremos a esse debate em momento oportuno.
} 
Observa-se, contudo, que no Agravo Regimental na Carta Rogatória 8279, julgado em 17 de junho de 1998, pelo Tribunal Pleno do STF, o Ministro relator Celso de Mello ressalta a necessidade de um processo para que os tratados e convenções internacionais passem produzir efeitos no ordenamento jurídico brasileiro. Afirma que

a Constituição brasileira não consagrou, em tema de convenções internacionais ou de tratados de integração, nem o princípio do efeito direto, nem o postulado da aplicabilidade imediata. Isso significa, de jure constituto, que, enquanto não se concluir o ciclo de sua transposição, para o direito interno, os tratados internacionais e os acordos de integração, além de não poderem ser invocados, desde logo, pelos particulares, no que se refere aos direitos e obrigações neles fundados (princípio do efeito direto), também não poderão ser aplicados, imediatamente, no âmbito doméstico do Estado brasileiro (postulado da aplicabilidade imediata) ${ }^{9}$.

Desta forma, defende que o Brasil teria se filiado ao dualismo.

\section{2 - Posição hierárquica ocupada pelos Tratados Internacionais no ordenamento jurídico brasileiro}

Esta matéria apresentou práticas distintas ao longo do tempo, inicialmente pela interpretação da à CF e, em momento seguinte, a partir da promulgação da EC n. ${ }^{\circ}$ 45/2004.

Antes da referida Emenda Constitucional, se observava a existência de duas grandes correntes que discorriam acerca da matéria.

A primeira delas respalda seu posicionamento no artigo $5^{\circ}, \S 2^{\circ}$ da Constituição Federal. Segundo parte da doutrina e da jurisprudência, os tratados internacionais que versem sobre direitos humanos adquirem status de norma constitucional. Já os tratados internacionais que tratem de matéria diversa da proteção dos direitos humanos ocupam a mesma posição hierárquica das leis ordinárias. Esta é a posição adotada, por exemplo, por Flávia Piovesan e Antônio Augusto Cançado Trindade.

A existência desta teoria se justifica na medida em que

os tratados de direitos humanos em nada se identificam com os tratados comuns e tradicionais, já que, enquanto estes buscam o equilíbrio e a reciprocidade de

\footnotetext{
${ }^{9}$ STF, CR AgR 8279, Relator Celso de Mello, Brasília, 17 de junho de 1998.
} 
relações entre Estados partes, aqueles transcendem os meros compromissos recíprocos entre os Estados pactuantes, objetivando a salvaguarda dos direitos do ser humano e não das prerrogativas dos Estados. Portanto, as diferenças entre estes tratados, por si só, justificam a existência da diversidade de regimes jurídicos a eles atribuídos. ${ }^{10}$

Nos termos do artigo $5^{\circ}, \S 2^{\circ}$ da Constituição Federal, os direitos e garantias expressos nesta Constituição não excluem outros decorrentes do regime e dos princípios por ela adotados, ou tratados internacionais em que a República Federativa do Brasil seja parte. Com base nessa norma, se tem considerado que os direitos e garantias arrolados na Carta Magna são exemplificativos, tendo a norma em questão caráter aberto, ou seja, possibilita a entrada no ordenamento jurídico de outros direitos e garantias decorrentes de tratados internacionais que não estejam previstos no texto constitucional. Além disso, o artigo $1^{\circ}$, III da Constituição Federal consagra como sendo fundamento da República Brasileira a dignidade da pessoa humana e o artigo $4^{\circ}$, II da Carta Magna afirma que o Brasil, em suas relações internacionais, rege-se pelo princípio da prevalência dos direitos humanos. Nesse sentido, os direitos e garantias decorrentes de tratados internacionais recebem tratamento especial, tendo status de norma constitucional.

Para Cançado Trindade,

cumpre, em nossos dias, no domínio da proteção dos direitos humanos, expressar no direito interno a medida e as conquistas do direito internacional, ao invés de tentar projetar nesse último a medida do direito interno. Importa aqui reduzir a distância ou brecha entre as óticas 'internacionalista' e 'constitucionalista'. Há que ressaltar a necessidade de, no presente contexto, buscar maior concordância entre direito internacional e o direito interno, maior aproximação entre enfoques internacionalista e constitucionalista, e conjunção da realidade interna com as possibilidades e meios de proteção internacional dos direitos humanos. $\mathrm{Na}$ verdade verifica-se uma confluência entre direito internacional e direito publico interno, na medida em que constitui objeto tanto de um quanto de outro a extensão ou garantia de proteção cada vez mais eficaz do cidadão, da pessoa humana. ${ }^{11}$

Alinhados com essa corrente, diversos países da América Latina dedicam, em suas constituições, dispositivos que regem as relações entre

\footnotetext{
${ }^{10}$ PIOVESAN, Flávia. Valor Jurídico dos Tratados: Impacto na Ordem Interna e Internacional. Disponível em: http://www.mundojuridico.adv.br. Acesso em 30 de abril de 2008. p. 17.

${ }_{11}$ TRINDADE, Antônio Augusto Cançado Apud CASTRO, Carlos Roberto Siqueira. A Constituição aberta e os direitos fundamentais. Editora Forense, 2003. p. 140.
} 
Direito Internacional e Direito Interno. A título de exemplo, é possível citar: o artigo 105 da Constituição do Peru de 1979, que atribui às normas de tratados internacionais de direitos humanos hierarquia constitucional; o artigo 46 da Constituição da Guatemala de 1985, que afirma que os tratados de direitos humanos ratificados prevalecem sobre o direito interno; o artigo $5^{\circ}$ da Constituição do Chile de 1989; e o artigo 93 da Constituição da Colômbia de $1991^{12}$. Sobre esse ponto, o constitucionalista Carlos Roberto Siqueira Castro afirma que:

passada a dura experiência do autoritarismo militar que se abateu sobre muitas nações, verifica-se já uma sadia efervescência do chamado Direito Constitucional Internacional voltado à proteção dos direitos fundamentais do homem. As Constituições latino-americanas dessa nova era têm dispensado uma reverência especial aos tratados de direitos humanos e aos preceitos neles consagrados. Fizeram-no, muitas delas, mediante a expressa incorporação dos tratados de cunho humanitarista à normatividade nacional, não raro no idêntico nível de positivação jurídica supralegal deferido às normas constitucionais respeitantes aos direitos e garantias individuais e coletivos, e revestindo-os, até mesmo, com o predicativo de cláusulas pétreas. Com isso, esses preceitos oriundos da ordem internacional restaram constitucionalizados e, além disso, tornaram-se imodificáveis pelas vias ordinárias de reforma constitucional. ${ }^{13}$

Segundo o artigo $5^{\circ}, \S 1^{\circ}$ da Constituição Federal Brasileira, as normas definidoras de direitos e garantias fundamentais têm aplicação imediata. Com base neste dispositivo, os tratados internacionais de direitos humanos têm aplicação automática, independentemente de edição de decreto de execução, produzindo efeitos no ordenamento jurídico logo após a ratificação pelo Chefe do Poder Executivo. Já os tratados internacionais que tratam de matéria diversa da proteção dos direitos humanos, para que passem a produzir efeitos, se faz necessária a edição do decreto de execução. Conforme defendido por Flávia Piovesan, a Constituição Federal adotou

\footnotetext{
${ }^{12}$ Art. 93. Los tratados y convenios internacionales ratificados por el Congreso, que reconocen los derechos humanos y que prohiben su limitación en los estados de escepción, prevalecen en el orden interno. Los deberes y derechos consagrados en esta Carta se interpretarán en conformidad con los tratados internacionales sobre derechos humanos ratificados por Colombia

${ }^{13}$ CASTRO, Carlos Roberto Siqueira. A Constituição aberta e os direitos fundamentais. Rio de Janeiro: Editora Forense, 2003. p. 150.
} 
um sistema jurídico misto, na medida em que para os tratados de direitos humanos acolhe a sistemática de incorporação automática, enquanto que para os tratados tradicionais acolhe a sistemática da incorporação não automática. ${ }^{14}$

A desembargadora Margarida Cantarelli também se apóia nesta vertente. No julgamento proferido por unanimidade pela Primeira Turma do TRF-5a Região, na AC 238.842-RN (2000.05.00.057989-2), julgado em 30/08/2001, afiram que o Pacto Internacional sobre Direitos Humanos e Políticos (1966) e a Convenção Americana sobre Direitos Humanos (1969), que foram ratificados pelo Brasil em 1992 e "muitos outros textos internacionais estão, nos termos da própria Constituição, à mesma equiparados, na melhor interpretação dada ao $\S 2^{\circ}$ do seu art. $5^{\circ}$.

A segunda corrente sobre a posição hierárquica ocupada pelos tratados internacionais no ordenamento jurídico brasileiro vinha sendo a seguida pelo Supremo Tribunal Federal. Os adeptos desta vertente afirmam que qualquer norma decorrente de tratado internacional possui status de lei ordinária, tendo caráter infraconstitucional. Utilizam como base o artigo 102, III, b da Constituição Federal e sua interpretação literal. Afirmam que, se a própria Constituição atribui competência ao STF para julgar, mediante recurso extraordinário, as causas decididas em única ou última instância, quando a decisão recorrida declarar a inconstitucionalidade de tratado ou lei federal, reconhece ela posição hierárquica inferior de todos os tratados internacionais, de direitos humanos ou não, face o texto constitucional.

Deduzem que, se é cabível recurso extraordinário em caso de decisão que 'declarar a inconstitucionalidade de tratado', não especificando o Constituinte que tipo de tratado seria, é porque 'quis' ele - o Constituinte - afirmar a superioridade da Constituição em face de todas fontes internacionais de direito. ${ }^{15}$

Além disso, defendem que, se a Carta Magna tratou da inconstitucionalidade de tratados internacionais e da inconstitucionalidade

\footnotetext{
${ }^{14}$ PIOVESAN, Flávia. Valor Jurídico dos Tratados: Impacto na Ordem Interna e Internacional. Disponível em: http://www.mundojuridico.adv.br. Acesso em 30 de abril de 2008. p. 15.

${ }^{15}$ LOPES, Anselmo Henrique Cordeiro. A força normativa dos tratados internacionais de direitos humanos $e \quad a$ Emenda Constitucional $n^{o}$ 45/2004. Disponível em http://jus2.uol.com.br/doutrina/texto.asp?id=6157 . Acesso em 10 de maio de 2008. p. 1.
} 
de lei federal na mesma alínea, teria atribuído a ambas a mesma hierarquia infraconstitucional.

Argumenta-se, ainda, que para que os tratados internacionais ingressem no ordenamento jurídico brasileiro, se faz necessária a edição de um decreto legislativo, aprovado por um quorum de maioria simples, de forma similar às leis ordinárias.

Soma-se a isso o fato de que a Constituição Federal Brasileira é rígida, ou seja, para que suas normas sejam alteradas se deve obedecer a um procedimento mais difícil do que para a alteração do restante das normas jurídicas. É justamente da rigidez que decorre a supremacia da constituição. Para que a Constituição Federal seja reformada, a proposta deve ser discutida e votada em cada Casa do Congresso Nacional, em dois turnos, considerando-se aprovada se obtiver, em ambos, três quintos dos votos dos respectivos membros (artigo 60, $\S 2^{\circ}$ da Constituição Federal). Desta forma, não se poderia admitir a alteração da Carta Magna por meio de tratado internacional, não tendo esse força de emenda constitucional. A própria constituição exige quorum especial para a reforma constitucional e tentar alterá-la por aprovação de quorum de maioria simples seria inconstitucional, tendo em vista a desobediência do processo legislativo para edição de emendas constitucionais.

\subsection{1 - O Pacto de San José da Costa Rica e os Códigos Civil de 1916 e de Processo Civil de 1973}

O Pacto de San José da Costa Rica, quando ingressou no ordenamento jurídico brasileiro, contrariava dispositivos tanto do Código Civil de 1916 como do de Processo Civil de 1973. Deste modo, se deve analisar qual norma prevaleceu.

Para a primeira corrente, não há muito que se discorrer. Sendo o Pacto de San José da Costa Rica norma constitucional, se sobrepõe a 
qualquer disposição infraconstitucional, anterior ou posterior, contrária a ele.

Seguindo a orientação da segunda corrente de que todos os tratados internacionais já ratificados ocupariam a mesma posição hierárquica das leis ordinárias, é possível se afirmar que o Pacto de San José da Costa Rica, com sua promulgação em 6 de novembro de 1992, teria derrogado todas as normas ordinárias anteriores que permitiam a prisão civil do depositário infiel.

\begin{abstract}
Afirma Valério de Oliveira Mazzuoli
sendo a Convenção Americana sobre Direitos Humanos (Pacto de San José da Costa Rica) norma de caráter geral, capaz somente de revogar normas de caráter também geral, é de se entender, sem muito esforço que, sendo o Código Civil de 1916 e o Código de Processo Civil leis gerais, tanto o art. 1.287 do primeiro diploma, quanto os arts. $902, \S 1^{\circ}$ e 904 , parágrafo único, do diploma processual, reputam-se derrogados pelo referido Pacto, que a eles sobreveio. ${ }^{16}$
\end{abstract}

Neste sentido, o artigo $7^{\circ}$, inciso 7 do Pacto de San José da Costa Rica ${ }^{17}$ se sobrepôs aos dispositivos do Código Civil de 1916 e do Código de Processo Civil, não sendo mais possível a decretação da prisão do infiel depositário.

Conforme será constatado no capítulo seguinte, reservado a análise de julgados, não foi majoritário o entendimento que defendia a revogação dos dispositivos ordinários pela Convenção.

\title{
1.2.2 - O Pacto de San José da Costa Rica e o Código Civil de 2002
}

Com a entrada em vigor do Novo Código Civil, em 10 de janeiro de 2003, a mesma disposição que havia no artigo 1287 do Código de 1916 foi repetida no artigo $652^{18}$. Desta forma, para cada uma das correntes

\footnotetext{
${ }^{16}$ MAZZUOLI, Valério de Oliveira. Prisão civil por divida e o Pacto de San José da Costa Rica. Rio de Janeiro: Forense, 2002. p. 94.

17 Artigo $7^{\circ}$, inciso 7 - Ninguém deve ser detido por dívidas. Este princípio não limita os mandatos de autoridade judiciária competente expedidos em virtude de inadimplemento de obrigação alimentar.

${ }^{18}$ Art. 652. Seja voluntário ou necessário o depósito, o depositário, que não restituir, quando exigido, será compelido a fazê-lo mediante prisão não excedente a 1 (um) ano, e ressarcir os prejuízos.
} 
mencionadas, é possível se dar uma resposta a essa mudança no ordenamento jurídico.

Para os defensores da primeira corrente, que afirma ter o Pacto de San José da Costa Rica status de norma constitucional, o artigo 652 do Novo Código Civil já nasceu dotado de inconstitucionalidade, por ser contrário ao artigo $7^{\circ}$, inciso 7 da Convenção, que veda a prisão civil do depositário infiel. Entretanto, sob a ótica da segunda corrente, ao se considerar que a Convenção Americana sobre Direitos Humanos tem força de lei ordinária, a partir da entrada em vigor do Novo Código Civil, o artigo $7^{\circ}$, inciso 7 da Convenção foi derrogado, tendo o artigo 652 do CC restabelecido a prisão civil do depositário infiel. Neste sentido, afirma Carvalho Neto que

em nosso entendimento, embora sempre houvesse permissão constitucional, não era possível no Brasil a prisão civil do depositário infiel, em face da inexistência de lei em vigor que a determinasse, sendo que a lei que a determinava foi revogada pela Convenção Americana sobre Direitos Humanos (Pacto de São José da Costa Rica), tendo agora, sido restabelecida pelo Novo Código Civil ${ }^{19}$

Estas duas correntes, vale lembrar, dividiam doutrina e jurisprudência antes da edição da Emenda Constitucional 45/2004.

\subsection{3 - $\bigcirc \S 3^{\circ}$ do artigo $5^{\circ}$ da Constituição Federal incluído pela Emenda Constitucional $n .^{\circ} 45 / 2004$}

Com a entrada em vigor da referida norma, o cenário, entretanto, se alterou. Esta Emenda trouxe significativas mudanças no que diz respeito ao Direito Internacional, que com a inclusão do artigo $5^{\circ}, \S 3^{\circ}$ no texto constitucional, mudou a abordagem que vinha sendo dada aos tratados internacionais, especialmente os que tratam de direitos humanos.

$\mathrm{O}$ artigo $5^{\circ}, \S 3^{\circ}$ da Constituição Federal, inserido na Carta Política pela Emenda Constitucional 45/2004, dispõe que os tratados e convenções

${ }^{19}$ CARVAlHO NETO, Inácio de. A prisão do depositário infiel, o Pacto de São José da Costa Rica e o Novo Código Civil. Disponível em http://www.mundojuridico.adv.br/cgibin/upload/texto639.rtf. Acesso em 10 de maio de 2008. p. 3. 
internacionais sobre direitos humanos que forem aprovados, em cada Casa do Congresso Nacional, em dois turnos, por três quintos dos votos dos respectivos membros, serão equivalentes às emendas constitucionais. Desta forma, se passou a exigir quorum especial e votação em dois turnos em ambas as Casas para que os tratados de direitos humanos ingressem no ordenamento jurídico brasileiro com status de norma constitucional.

Esse dispositivo, entretanto, não deu fim aos debates. Discussões acerca da posição hierárquica dos tratados internacionais ratificados antes da edição da Emenda em questão continuam surgindo e, neste sentido, indaga-se que status normativo eles teriam.

Como todas as convenções, inclusive as de direitos humanos, não passaram até hoje pelo escrutínio descrito, não teriam elas, assim, eficácia de emenda constitucional. Eis a interpretação autêntica - porque subscrita pelo próprio Constituinte - dada EC n ${ }^{\circ}$ 45/2004: os documentos normativos internacionais de direitos humanos anteriores a ela - a EC 45 - não têm altura constitucional, e somente passarão a tê-la após votação especial em dois turnos, pela maioria de três quintos, em cada Casa Parlamentar. Destarte, a Reforma em análise veio a expressar a posição abraçada pela visão restritiva do Supremo Tribunal Federal e dos autores que o seguem. ${ }^{20}$

Contudo, ao se considerar que os tratados internacionais de direitos humanos ratificados antes da Emenda Constitucional 45/2004 já possuíam status de norma constitucional, versando eles sobre garantias e direitos fundamentais, conforme defendido pela primeira corrente, qualquer emenda tendente a abolí-los será inconstitucional, nos termos do artigo $60, \S 4^{\circ}$, IV da Constituição Federal ${ }^{21}$. Desta forma, só se pode concluir que a Emenda Constitucional 45/2004 se aplica apenas a tratados de direitos humanos que ainda não foram ratificados, mantendo os anteriores a ela o status de norma constitucional, mesmo que não tenham sido aprovados por quorum especial e nem tenham sido votados em dois turnos em ambas as Casas do Congresso Nacional.

\footnotetext{
${ }^{20}$ LOPES, Anselmo Henrique Cordeiro. A força normativa dos tratados internacionais de direitos humanos $e$ a Emenda Constitucional $n^{o}$ 45/2004. Disponível em http://jus2.uol.com.br/doutrina/texto.asp?id=6157 . Acesso em 10 de maio de 2008.

${ }^{21}$ Art. $60 . \S 4{ }^{\circ}$ Não será objeto de deliberação a proposta de emenda tendente a abolir: IV - os direitos e garantias individuais.
} 
Pela visão da segunda corrente, os tratados internacionais de direitos humanos ratificados após a referida Emenda somente adquirirão status de norma constitucional se adotarem o procedimento previsto no artigo $5^{\circ}, \S 3^{\circ}$ da Constituição Federal. Aqueles que não passarem por este rito terão força de lei ordinária.

Observa-se que o referido artigo abriu para o Congresso Nacional uma discricionariedade, podendo optar submeter o tratado de direitos humanos a votação especial ou não.

Os que defendiam que qualquer norma decorrente de tratado internacional teria caráter infraconstitucional e força de lei ordinária, com a edição da Emenda 45/2004, afirmam que os tratados ratificados antes da referida Emenda somente poderão adquirir status normativo de emenda constitucional se passarem por uma nova deliberação nas Casas do Congresso Nacional, devendo ser aprovado pelo quorum especial de três quintos, nos termos do artigo $5^{\circ}, \S 3^{\circ}$ da Constituição Federal.

Outra questão que também não ficou bem definida é quanto à necessidade de ratificação pelo Chefe do Poder Executivo dos tratados de direito internacional que forem aprovados no âmbito do dispositivo analisado. O artigo 84, VIII da Constituição Federal, conforme já analisado, atribui competência privativa ao Presidente da República para celebrar tratados, convenções ou atos internacionais. Porém, parte da doutrina tem entendido que o decreto de promulgação não seria mais uma exigência. Isso porque um tratado votado nos termos do artigo $5^{\circ}, \S 3^{\circ}$ da Constituição Federal tramitará pelo Congresso Nacional como se projeto de emenda constitucional fosse e não como projeto de decreto legislativo. Desta forma, não estaria sujeita a ratificação do Presidente da República e sua promulgação se daria pelo Congresso Nacional e não por decreto do Executivo.

Flávia Piovesan ainda discorre sobre outra alternativa para a solução de conflitos entre a Constituição e tratados internacionais de direitos humanos. 
Poder-se-ía imaginar, como primeira alternativa, a adoção do critério 'lei posterior revoga lei anterior com ela incompatível', considerando a natureza constitucional dos tratados internacionais de direitos humanos. Todavia, um exame mais cauteloso da matéria aponta a um critério de solução diferenciado, absolutamente peculiar ao conflito em tela, que se situa no plano dos direitos fundamentais. E o critério a ser adotado se orienta pela escolha da norma mais favorável à vítima. ${ }^{22}$

Utilizando como base o critério da norma mais favorável à vítima, a escolha de qual regra será aplicada ficará a cargo do Poder Judiciário no momento em que analisar o caso concreto. Desta forma, deve prevalecer a norma mais benéfica, a que prioriza a defesa da dignidade da pessoa humana.

As normas de direitos humanos não têm caráter restritivo de direitos. Elas devem ser sempre invocadas no sentido de ampliar e fortalecer direitos já previstos nos ordenamentos jurídicos internos.

Este princípio também é defendido por Cançado Trindade, que afirma

no domínio da proteção dos direitos humanos, interagem o direito internacional e o direito interno movidos pelas mesmas necessidades de proteção, prevalecendo as normas que melhor protejam o ser humano. A primazia é da pessoa humana. ${ }^{23}$

Flávia Piovesan utiliza como exemplo de aplicação deste princípio no conflito existente entre o artigo $7^{\circ}$, inciso 7 da Convenção Americana sobre Direitos Humanos, que veda a prisão civil por dívida (autorizando apenas a prisão do devedor de alimentos) e o artigo $5^{\circ}$, LXVII da Constituição Federal, que permite a prisão do depositário infiel. Segundo a autora, utilizando como base a lei mais benéfica à vítima, se deve afastar a aplicação da norma constitucional, neste caso. Isso porque, ao se contrapor o direito a liberdade e o direito a propriedade, com base na primazia da pessoa humana, o primeiro deve prevalecer sobre o segundo. Afirma, ainda, que se em outro caso o dispositivo constitucional fosse o mais favorável, a norma de direito internacional teria que ser afastada.

\footnotetext{
${ }^{22}$ PIOVESAN, Flávia. Valor Jurídico dos Tratados: Impacto na Ordem Interna e Internacional. Disponível em: http://www.mundojuridico.adv.br. Acesso em 30 de abril de 2008. p. 19.

${ }^{23}$ TRINDADE, Antônio Augusto Cançado Apud RAMOS, André de Carvalho. Teoria geral dos direitos humanos na ordem internacional. Rio de Janeiro: Renovar, 2005. p. 103.
} 
$\mathrm{O}$ conflito entre as normas de Direito Internacional, mais especificamente o Pacto de San José da Costa Rica, e as regras do Direito interno brasileiro será objeto de análise mais profunda no capítulo seguinte. 


\section{2 - A possibilidade da prisão do depositário infiel e a constitucionalidade do Pacto de San José da Costa Rica}

O Pacto de San José da Costa Rica, criado em 22 de novembro de 1969, foi aprovado pelo Decreto Legislativo 27, tendo sido ratificado, sem ressalvas, pelo Brasil em 25 de setembro de 1992. Porém, apenas com o Decreto Executivo 678, de 06 de novembro de 1992, passou a integrar o ordenamento jurídico brasileiro.

A tardia ratificação do Brasil a esse tratado pode ser explicada já que a política externa brasileira na questão dos direito humanos, em decorrência do regime ditatorial que vigorou por cerca de vinte anos após o golpe de 1964, foi muito resistente em aderir à via jurídica de proteção dos direitos fundamentais do homem, na medida em que essa adesão importaria por certo na revelação das práticas cruéis de repressão política então disseminadas e na vulnerabilidade da imagem dos sucessivos governos militares perante o concerto das nações desenvolvidas da Europa e da América do Norte. ${ }^{24}$

Este tratado internacional, em seu art. $7^{\circ}$, inciso 7 dispõe que "ninguém deve ser detido por dívida. Este princípio não limita os mandados de autoridade judiciária competente expedidos em virtude de inadimplemento de obrigação alimentar". A norma veda expressamente a prisão civil por dívida, autorizando apenas a do devedor de pensão alimentícia.

A Constituição da República Federativa do Brasil, país signatário do Pacto de San José da Costa Rica, em seu artigo, $5^{\circ}$, LXVII ${ }^{25}$, autoriza a prisão do depositário infiel. Neste sentido, se observa um conflito entre a norma internacional e a norma constitucional.

A questão não é pacífica tanto para os que defendem que o tratado em questão possui status de norma constitucional como para aqueles que afirmam que ele possui força de lei ordinária.

Segundo entendimento de parte da doutrina e da jurisprudência, o artigo $5^{\circ}$, LXVII da Constituição Federal deve prevalecer sobre o artigo $7^{\circ}$,

\footnotetext{
${ }^{24}$ CASTRO, Carlos Roberto Siqueira. A Constituição aberta e os direitos fundamentais. Rio de Janeiro: Editora Forense, 2003. p.139.

${ }^{25}$ Art. $5^{\circ}$, LXVII - não haverá prisão civil por dívida, salvo a do responsável pelo inadimplemento voluntário e inescusável de obrigação alimentícia e a do depositário infiel.
} 
inciso 7 do Pacto de San José da Costa Rica. Isso porque a norma constitucional em questão, tanto a parte que proíbe a prisão civil por dívida, quanto a ressalva referente à prisão do depositário infiel, é direito fundamental. Esta norma, inserida dentro do Título II da Carta Magna, reservado a direitos e garantias fundamentais, tem conteúdo intocável, que não pode ser modificado pelo Poder Reformador, tendo natureza de cláusula pétrea, nos termos do artigo $60, \S 4^{\circ} \mathrm{IV}$ da Constituição Federal. Sendo assim, a norma internacional que contraria este dispositivo da Constituição é inconstitucional, devendo sua aplicação ser afastada da ordem jurídica brasileira.

Os que defendem a primazia do artigo $7^{\circ}$, inciso 7 do Pacto de San José da Costa Rica sobre o artigo 5º, LXVII da Constituição Federal afirmam que apenas a primeira parte, que veda a prisão civil por dívida, do dispositivo constitucional seria cláusula pétrea. A ressalva do artigo, que autoriza a prisão do depositário infiel, não seria um direito fundamental e sim uma exceção a ele. Desta forma, a segunda parte do dispositivo constitucional não seria imutável, podendo ser modificado pelo Poder Constituinte Derivado.

É um direito fundamental, consagrado no Pacto, não ser preso por dívida que não seja decorrente de inadimplemento de obrigação alimentar.

Além do conflito existente entre o tratado internacional e a Constituição Federal, se constata outro confronto, este contra o tratado internacional e a legislação infraconstitucional que rege a prisão civil por dívida, previamente autorizada pela própria Constituição.

No Brasil, os debates jurisprudenciais permeiam, principalmente, o conflito entre o artigo $7^{\circ}$, inciso 7 do Pacto de San José da Costa Rica e o artigo $5^{\circ}$, LXVII da Constituição Federal, ou seja, entre a norma internacional e a norma constitucional.

Ocorre que, tendo o Pacto de San José da Costa Rica sido ratificado pelo Chefe do Executivo em 1992, passou a ser utilizado como fundamento na impetração de Habeas Corpus preventivos com o intuito de evitar a 
prisão civil dos devedores de dívidas garantidas por alienação fiduciária, devedores estes considerados depositários infiéis. Cabe ainda lembrar que o artigo 11 do Pacto de Direitos Civis e Políticos de 1966 também veda a prisão civil por dívida ${ }^{26}$. O Brasil é signatário deste pacto, que vigora no território desde 1992.

Isto posto, cabe analisar a forma como o Supremo Tribunal Federal e o Superior Tribunal de Justiça vêm tratando o assunto. Estes tribunais têm dado interpretações jurisprudenciais diferentes à mesma questão.

O Supremo Tribunal Federal não vinha aceitando atribuir aos tratados internacionais de direitos humanos já ratificados status de norma constitucional. Neste sentido, decidiu em favor da constitucionalidade da prisão civil do depositário infiel, aplicando o artigo $5^{\circ}$, LXVII da Constituição Federal em detrimento do artigo $7^{\circ}$, inciso 7 do Pacto de San José da Costa Rica. Vale lembrar, conforme já exposto no capítulo anterior, que os que defendem essa posição afirmam que qualquer norma decorrente de tratado internacional possui status de lei ordinária, tendo caráter infraconstitucional de acordo com a interpretação dada pelo artigo 102, III, b da Constituição Federal.

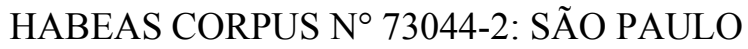

Relator: Maurício Corrêa

Data do julgamento: 19/03/1996

Órgão julgador: Segunda Turma

EMENTA: "HABEAS-CORPUS" PREVENTIVO. PRISÃO CIVIL DE DEPOSITÁRIO INFIEL DECRETADA EM AÇÃO DE DEPÓSITO DE BEM ALIENADO FIDUCIARIAMENTE (ART. 66 DA LEI N. ${ }^{\circ}$ 4728/65 E DECRETO-LEI N. ${ }^{\circ}$ 911/69): ART. $5^{\circ}$, LXVII DA CONSTITUICAO FEDERAL E CONVENÇÃO AMERICANA SOBRE DIREITOS HUMANOS (PACTO DE SÃO JOSÉ DA COSTA RICA). DECR. N. ${ }^{\circ} 678 / 92$. ALEGAÇÃO DE PRESCRIÇÃO DA PRETENSÃO PUNITIVA.

3 - A prisão de quem foi declarado, por decisão judicial, como depositário infiel é constitucional, seja quanto ao depósito regulamentado no Código Civil como no caso de alienação protegida pela cláusula fiduciária.

4 - Os compromissos assumidos pelo Brasil em tratado internacional de que seja parte ( $\S 2^{\circ}$ do art. $5^{\circ}$ da Constituição) não minimizam o conceito de soberania do Estado-povo na elaboração de sua Constituição; por esta razão, o $\operatorname{art.~} 7^{\circ}, \mathrm{n}^{\circ} 7$, do Pacto de São José da Costa Rica, ("ninguém deve ser detido por dívida": "este

\footnotetext{
${ }^{26}$ Artigo 11 - Ninguém poderá ser preso apenas por não poder cumprir com uma obrigação contratual.
} 
princípio não limita os mandados de autoridade judiciária competente expedidos em virtude de inadimplemento de obrigação alimentar") deve ser interpretado com as limitações impostas pelo art. $5^{\circ}$, LXVII, da Constituição.

Já o Superior Tribunal de Justiça, vinha aplicando o artigo $7^{\circ}$, inciso 7 do Pacto de San José da Costa Rica. Este Tribunal tinha atribuído a norma em questão status de emenda constitucional e vinha considerando o direito do ser humano não ser preso por dívida, salvo os casos de inadimplemento de obrigação alimentícia, um direito fundamental, constitucionalmente protegido.

Neste sentido, seguiremos este trabalho fazendo uma digressão histórica, analisando o posicionamento desses dois tribunais ao longo de uma certa época. Serão utilizados como momento de corte os seguintes períodos:

1) a partir de 1992, ano em que foi ratificado o Pacto de San José da Costa Rica, até 2002, quando foi promulgado o Novo Código Civil;

2) de 2002 a 2004, ano da edição da Emenda Constitucional n. ${ }^{\circ}$ 45/2004;

3) de 2003 até o presente momento.

\section{1 - $O$ entendimento do Supremo Tribunal Federal}

A época do ingresso do Pacto de San José da Costa Rica no ordenamento jurídico brasileiro, após sua ratificação e promulgação em 1992, observa-se a existência de uma divergência dentro do Tribunal sobre a possibilidade de se aplicar ou não os tratados de direitos humanos com preceitos divergentes dos vigentes na Constituição Federal.

O entendimento majoritário vinha sendo no sentido de que a prisão civil do depositário é constitucional, não tendo sido revogada pelo Pacto de San José da Costa Rica. Esta posição, que pode até mesmo ser considerada uma visão de certa forma conservadora, prioriza a Constituição Federal em 
detrimento das normas internacionais de direitos humanos que vedam a prisão civil por dívida, autorizando apenas a prisão do devedor de alimentos.

O HC 72.131 / RJ é um dos "leading cases" desta vertente da posição que foi vencedora. O habeas corpus foi indeferido, tendo prevalecido a posição do Ministro Moreira Alves, sendo ele seguido pela maioria do plenário. Tiveram votos vencidos os Ministros Marco Aurélio, Francisco Rezek, Carlos Velloso e Sepúlveda Pertence, que acompanharam o voto do Ministro relator Marco Aurélio, que defendeu a concessão do HC com base no Pacto em questão.

HC 72131-1/RJ

Relator: Ministro Marco Aurélio

Data do julgamento: 23/11/1995

Órgão julgador: Tribunal Pleno

EMENTA: habeas corpus. Alienação fiduciária em garantia. Prisão civil do devedor como depositário infiel.

- Sendo o devedor, na alienação fiduciária em garantia, depositário necessário por força de disposição legal que não desfigura essa caracterização, sus prisão civil, em caso de infidelidade, se enquadra na ressalva contida na parte final do artigo $5^{\circ}$, LXVII, da Constituição de 1988.

- Nada interfere na questão do depositário infiel em matéria de alienação fiduciária o disposto no $\S 7^{\circ}$ do artigo $7^{\circ}$ da Convenção de Sano José da Costa Rica.

habeas corpus indeferido, cassada a liminar concedida.

Afirma o Ministro Marco Aurélio que o Decreto-Lei n ${ }^{0}$ 911/69, que autorizava prisão do devedor de alienação fudiciária, ${ }^{27}$ teria sido derrogado pelo Pacto de San José da Costa Rica. Tendo o Brasil ratificado o tratado sem ter feito nenhuma ressalva, o artigo $7^{\circ}$, inciso 7 , da Convenção não pode ter sua aplicabilidade afastada. Neste sentido, argumenta que

ainda que se pudessem colocar em plano secundário os limites constitucionais, a afastarem, a mais não poder, a possibilidade de subsistir a garantia da satisfação do débito como meio coercitivo, no caso da alienação fiduciária, que é a prisão, tem-se que essa, no que decorre não da Carta Política da República, que para

${ }^{27}$ Decreto-Lei n. ${ }^{\circ} 911$ de 01/10/1969

Art. $1^{\circ}$. O Artigo 66 da lei n. ${ }^{\circ} 4728$ de 14 de julho de 1965 passa a ter a seguinte redação:

Art. 66. A alienação fiduciária em garantia transfere ao credor o domínio resolúvel e a posse indireta da coisa móvel alienada, independentemente da tradição efetiva do bem, tornando-se o alienante ou devedor em possuidor direto e depositário com todas as responsabilidades e encargos que lhe incumbem de acordo com a lei civil e penal". 
mim não a prevê, mas do Decreto-Lei $\mathrm{n}^{0}$ 911/69, já não subsiste na ordem jurídica em vigor, porquanto o Brasil mediante o Decreto $\mathrm{n}^{\mathbf{0}} 678$, de 6 de novembro de 1922, aderiu à Convenção Americana Sobre Direitos Humanos, ao chamado Pacto de São José da Costa Rica, de 22 de novembro de 1969. É certo que somente o fez cerca de vinte e dois anos após a formalização. Entrementes, a adoção mostrou-se linear, consignado o artigo primeiro do Decreto mediante o qual promulgou a citada Convenção que a mesma há de ser cumprida tão inteiramente como nela se contém. Ora, o inciso VII do artigo $7^{\underline{0}}$ revela que: "ninguém deve ser detido por dívida. Este princípio não limita, os mandatos de autoridade jurídica competente expedidos em virtude de inadimplemento de obrigação alimentar". ${ }^{28}$

Desta forma, observa-se que apenas a prisão em decorrência da inadimplência de obrigação alimentícia é autorizada.

Prossegue o Ministro citando o artigo $5^{\circ}$, $\S 2^{\circ}$ da Constituição

Federal que reconhece que os tratados internacionais são fontes de direitos individuais.

O Pacto de San José da Costa Rica, ao ser promulgado, teria adquirido status de lei ordinária, tendo força para revogar o Decreto-Lei $911 / 69$.

Assim, a nova disciplina da matéria, ocorrida a partir de 6 de novembro de 1992, implicou a derrogação do Decreto-Lei $\mathrm{n}^{\mathrm{o}}$ 911/69, no que se tinha como abrangente da prisão civil na hipótese de alienação fiduciária. O preceito da Convenção Americana Sobre Direitos Humanos a viger com estatura de legislação ordinária, suplantando, assim, enfoques em contrário, relativamente a essa última, até então em vigor.[...] A não se entender dessa forma, assentar-se-á a convivência de dispositivos conflitantes: o primeiro, o do Decreto-Lei no ${ }^{\circ}$ 911/69 relativo à possibilidade de chegar-se à prisão por dívida no caso de financiamento, simples financiamento, mediante alienação fiduciária, o segundo, em vigor a partir de $1992 \mathrm{e}$, portanto posterior, contendo o limite exaustivo à citada prisão, jungindo-a apenas às obrigações de alimentar. A óptica discrepa da ordem jurídica em vigor. Reconhecida a igualação dos diplomas - tanto o Decreto-Lei quanto a Convenção estão no âmbito da legislação ordinária forçoso é concluir que a última, disciplinando a matéria de forma contrária, resultou na revogação do primeiro. ${ }^{29}$

Já o Ministro Moreira Alves, defensor da posição vencedora, afirma que, tendo o Pacto de San José da Costa Rica natureza infraconstitucional, não pode este prevalecer sobre a Carta Magna, restringindo-lhe o alcance e a aplicabilidade. Em seu voto, afirma ser

pacífico na jurisprudência desta Corte que os tratados internacionais ingressam em nosso ordenamento jurídico tão somente com força de lei ordinária (o que

\footnotetext{
${ }^{28}$ STF, HC 72131, Relator Marco Aurélio, Brasília, 23 de novembro de 1995.

${ }^{29}$ STF, HC 72131, Relator Marco Aurélio, Brasília, 23 de novembro de 1995.
} 
ficou ainda mais evidente em face de o artigo 105, III, da Constituição que capitula, como caso de recurso especial a ser julgado pelo Superior Tribunal de Justiça como ocorre com relação à lei infraconstitucional, a negativa de vigência de tratado ou a contrariedade a ele), não se lhes aplicando, quando tendo eles integrado nossa ordem jurídica posteriormente à Constituição de 1988, o disposto no artigo $5^{\underline{0}}, \S 2^{\circ}$, pela singela razão de que não se admite emenda constitucional realizada por meio de ratificação de tratado. ${ }^{30}$

Defende que o Decreto-Lei 911/69 é lei especial em matéria de alienação fiduciária, tendo a Convenção caráter geral, não tem esta força para revogar tal Decreto-Lei.

Sendo o artigo $7^{\circ}, \S 7^{\circ}$, dessa Convenção norma de caráter geral, não revoga ele o disposto, em legislação especial, como é a relativa à alienação fiduciária em garantia, no tocante à sua disciplina do devedor como depositário necessário, suscetível de prisão civil se se tornar depositário infiel. ${ }^{31}$

No mesmo sentido, foi o voto do Ministro Maurício Correa, defendendo que a uma norma decorrente de um tratado não tem status de emenda constitucional, podendo ser objeto de ação de inconstitucionalidade, sujeitando-se ao controle exercido pelo Supremo Tribunal Federal, a quem é atribuído o papel de guarda da Constituição.

Em seu voto diferencia dois tipos de dívidas: as contraídas no cotidiano e as abrangidas por situações especiais. Para o Ministro, o depositário infiel, assim como o devedor em alienação fiduciária se enquadrariam na segunda hipótese. Desta forma, o artigo $7^{\circ}$, inciso 7 do Pacto de San José da Costa Rica

ao referi-se que ninguém será preso por divida, evidentemente que se está a dizer pleonasticamente, aquilo que a tradição constitucional pátria já consagrou, e de resto o mundo, de que ninguém será preso porque deixou de pagar uma obrigação contraída nas relações negociais que envolve o dia-a-dia das pessoas nos múltiplos intercâmbios da atividade econômica, quando não abrangidas por situações jurídicas especiais e particularíssimas ${ }^{32}$,

não se aplicando ao caso analisado a Convenção.

O Ministro defende, ainda, que a Constituição, em seu artigo $5^{\circ}$, LXVII, não distingue, no caso do depositário infiel, o depósito voluntário

\footnotetext{
${ }^{30}$ STF, HC 72131, Relator Marco Aurélio, Brasília, 23 de novembro de 1995.

${ }^{31}$ STF, HC 72131, Relator Marco Aurélio, Brasília, 23 de novembro de 1995.

${ }^{32}$ STF, HC 72131, Relator Marco Aurélio, Brasília, 23 de novembro de 1995.
} 
do depósito legal, como se pode ver no trecho de seu voto transcrito a seguir.

Não me parece que o inciso LXVII ao fazer menção expressa ao depositário infiel, admitindo a prisão civil restrinja a sua abrangência apenas ao depósito voluntário, excluindo-se o legal, decorrente do contrato, naquelas hipóteses em que é disciplinado e definido pela própria lei. ${ }^{33}$

O Ministro Francisco Rezek inicia seu voto lembrando ser esta a primeira vez que o plenário do tribunal delibera sobre o artigo $7^{\circ}$, inciso 7 da Convenção. Compara a situação no Brasil com a dos Estados Unidos da América, afirmando que em ambos os Estados, os tratados internacionais não têm força para mudar a Constituição.

Confirma o que já foi dito ao constatar que a norma oriunda de um tratado internacional tem status de lei ordinária e que, havendo conflito entre a norma e a Carta Magna, esta última deve prevalecer.

Dá-se prevalência sempre a Carta, embora isso não nos exonere de responder, internacionalmente, pelo ato ilícito - conscientemente em adotar, pelos meios rotineiros, um compromisso que não poderíamos honrar, culpa da inadvertência dos poderes políticos do Estado. ${ }^{34}$

Segundo o Ministro, não haveria conflito entre o Pacto de San José da Costa Rica e o artigo $5^{\circ}$, LXVII da Constituição Federal. Isso porque a ressalva que autoriza a prisão civil do depositário infiel não se configura como uma obrigação e sim uma autorização ao legislador ordinário para que este a regule.

Não estou lendo na lei fundamental nada de semelhante a 'Prenda-se o depositário infiel', mas apenas uma autorização para que o legislador ordinário, caso queira, tome esse caminho. O legislador ordinário o tomou. ${ }^{35}$

Com a ratificação do Pacto, houve uma revogação da norma infraconstitucional que regulava a prisão civil, o que não significa que uma norma futura não possa estabelecer novamente este instituto. Já que a Convenção "não derroga o instituto do depósito, em absoluto, mas tudo aquilo que, na legislação ordinária, facultava a prisão civil do depositário

\footnotetext{
${ }^{33}$ STF, HC 72131, Relator Marco Aurélio, Brasília, 23 de novembro de 1995.

${ }^{34}$ STF, HC 72131, Relator Marco Aurélio, Brasília, 23 de novembro de 1995.

${ }^{35}$ STF, HC 72131, Relator Marco Aurélio, Brasília, 23 de novembro de 1995.
} 
infiel" ${ }^{36}$ Sendo assim, a única forma de prisão civil que não teria sido revogada seria a decorrente do inadimplemento da obrigação alimentícia.

O Ministro Ilmar Galvão vota no mesmo sentido do Ministro Moreira Alves. Afirma que a norma do Pacto de San José da Costa Rica é norma de caráter geral, não devendo ela prevalecer sobre os dispositivos que cuidam especificamente do depósito e da alienação fiduciária.

Trata-se, alias, da única interpretação razoável suscetível de ser dada a norma sob apreciação, instituída pelo referido Pacto. Pelo singelo motivo de não ser possível admitir que, não apenas o Brasil, mas também os demais paises que subscreveram a Convenção de São José, ou a ela aderiram, na maioria subdesenvolvidos, houvessem tido a iniciativa de esvaziar de eficácia a garantia representada pelo depósito embutido nos contratos acima enumerados, ao despojá-los do elemento coercitivo que lhe confere o prestígio que tem como garantia, deixando praticamente à mingua de qualquer proteção a instituição do crédito, unanimemente tida como a mola propulsora da atividade econômica e, portanto, do desenvolvimento.

Ainda que assim não fosse, estar-se-ia diante de norma de caráter geral que não tem o direito de revogar leis de natureza especial como o são as acima citadas, no que toca à previsão da prisão civil. ${ }^{37}$

O Ministro Carlos Vellozo, por sua vez, acompanhou o voto do relator. Afirma ser o Pacto de San José da Costa Rica fonte de direitos fundamentais, com base no artigo $5^{\circ}, \S 2^{\circ}$ da Carta Magna. Isso porque constata que haveriam três tipos de direitos fundamentais decorrentes do que dispõe a Constituição de 1988: “a) direitos e garantias expressos na Constituição; b) direitos e garantias decorrentes do regime e dos princípios adotados pela Constituição; c) direitos e garantias inscritos nos tratados internacionais firmados pelo Brasil". ${ }^{38}$ Desta forma, a norma do artigo $7^{\circ}$, inciso 7 da Convenção estaria no mesmo patamar dos direitos e garantias expressos na própria Carta ou decorrentes dos princípios adotados, tendo força para revogar normas infraconstitucionais.

A prisão do depositário infiel está expressamente autorizada pela Constituição, art. $5^{\circ}$, LXVII, penso que a norma do Tratado não a revoga, revoga, sim, prisões civis inscritas em normas infraconstitucionais. [...] Se se entender, como parece ser a tendência do Tribunal, que a norma do Tratado incorporou-se ao direito interno como norma infraconstitucional, equiparada a lei ordinária, nem assim as prisões civis decorrentes de equiparações e de ficções legais continuariam de pé.

\footnotetext{
${ }^{36}$ STF, HC 72131, Relator Marco Aurélio, Brasília, 23 de novembro de 1995.

${ }^{37}$ STF, HC 72131, Relator Marco Aurélio, Brasília, 23 de novembro de 1995.

${ }^{38}$ STF, HC 72131, Relator Marco Aurélio, Brasília, 23 de novembro de 1995.
} 
O Tratado, posterior à norma infraconstitucional, paralisaria a eficácia daquelas normas infraconstitucionais que, mediante equiparações e ficções legais, autorizam a prisão do devedor inadimplente. Teríamos, no caso, aplicação da velha regra lex posterior derogat legi priori. ${ }^{39}$

O Ministro Celso de Mello argumenta no sentido de que as normas decorrentes de tratados internacionais não teriam força para alterar dispositivo da Carta Magna.

Os tratados internacionais não podem transgredir a normatividade emergente da Constituição, pois, além de não disporem de autoridade para restringir a eficácia jurídica das cláusulas constitucionais, não possuem força para conter ou para delimitar a esfera de abrangência normativa dos preceitos inscritos no texto da Lei Fundamental. ${ }^{40}$

Assim como o HC 72.131 / RJ, foi citado em diversos habeas corpus, com o objetivo de fundamentar o argumento de que a prisão civil seria possível no ordenamento jurídico brasileiro, o RE 206482/SP, de 27 de maio de 1998. Este julgado também é visto como um dos "leading cases" da posição majoritária do Supremo Tribunal Federal.

\author{
HC 206482/SP \\ Relator: Ministro Maurício Corrêa \\ Data do julgamento: 27/05/1998 \\ Órgão julgador: Tribunal Pleno
}

EMENTA: RECURSO EXTRAORDINÁRIO. DECRETO-LEI 911/69. DEPOSITÁRIO INFIEL. PRISÃO CIVIL. INCOMPATIBILIDADE COM A NOVA ORDEM CONSTITUCIONAL. INEXISTÊNCIA. MINISTÉRIO PÚBLICO. LEGITIMIDADE PARA RECORRER DA DECISÃO QUE CONCEDE HABEAS-CORPUS.

1. Habeas-corpus. Concessão. Ministério Público. Legitimidade para recorrer da decisão. Precedente.

2. O Decreto-lei 911/69 foi recebido pela nova ordem constitucional e a equiparação do devedor fiduciante ao depositário infiel não afronta a Carta da República, sendo legítima a prisão civil daquele que descumpre, sem justificativa, ordem judicial para entregar a coisa ou seu equivalente em dinheiro, nas hipóteses autorizadas por lei. Recurso extraordinário conhecido e provido.

Merecem destaque, nesta decisão, os votos dos Ministros Carlos Velloso e, em sentido contrário, Celso de Mello, cuja posição foi vencedora.

O Ministro Carlos Velloso afirma que o artigo $7^{\circ}$, inciso 7 da Convenção teria revogado todas as leis ordinárias anteriores que

\footnotetext{
${ }^{39}$ STF, HC 72131, Relator Marco Aurélio, Brasília, 23 de novembro de 1995.

${ }^{40}$ STF, HC 72131, Relator Marco Aurélio, Brasília, 23 de novembro de 1995.
} 
determinavam a prisão do depositário infiel, bem como aqueles dispositivos que equiparavam a ele o devedor inadimplente, ${ }^{41}$ "noutras palavras, as equiparações, feitas por normas infraconstitucionais, de devedor inadimplente a depositário infiel não tem aplicação diante do que está disposto na Convenção". 42

Soma-se a isso o fato de que, segundo ele, "a norma inscrita no art. $5^{\circ}$, LXVII, da CF, não é norma que determina a prisão do depositário infiel, mas é norma que simplesmente autoriza essa prisão, tratando-se, evidentemente, de autêntico depositário infiel". 43

Contrariamente, o Ministro Celso de Mello argumenta que não existe no ordenamento jurídico brasileiro norma de Direito Internacional que se sobreponha a Constituição Federal. "Inexiste, na perspectiva do modelo constitucional vigente no Brasil, qualquer precedência ou primazia hierárquico-normativa dos tratados ou convenções internacionais sobre o direito positivo interno". 44

Neste sentido, não se pode atribuir ao Pacto de San José da Costa Rica força para se revogar norma constitucional, já que ele tem status de lei ordinária.

A ordem constitucional vigente no Brasil não pode sofrer interpretações que conduza ao reconhecimento de que o Estado brasileiro, mediante convenção internacional, ter-se-ia interditado a possibilidade de exercer, no plano interno, a competência institucional que lhe foi outorgada expressamente pela própria Constituição da República ${ }^{45}$.

Nos primeiros casos que chegaram ao Supremo Tribunal Federal, após a ratificação do Pacto de San José da Costa Rica, questionando a possibilidade ou não da prisão civil, é possível se observar uma divergência marcante, com argumentos importantes para ambos os lados, tanto o que defendia a aplicação do artigo $7^{\circ}$, inciso 7 da Convenção, afastando assim a prisão do depositário infiel, quanto no sentido de não conceder habeas

\footnotetext{
${ }^{41}$ No julgado analisado, o Decreto-Lei 911/69, em seu artigo $1^{\circ}$, equipara ao depositário infiel o devedor em alienação fiduciária.

${ }^{42}$ STF, RE 206482, Relator Maurício Corrêa, Brasília, 27 de maio de 1998.

${ }^{43}$ STF, RE 206482, Relator Maurício Corrêa, Brasília, 27 de maio de 1998.

${ }^{44}$ STF, RE 206482, Relator Maurício Corrêa, Brasília, 27 de maio de 1998.

${ }^{45}$ STF, RE 206482, Relator Maurício Corrêa, Brasília, 27 de maio de 1998.
} 
corpus afirmando não ter o tratado em questão força para revogar a legislação vigente que determina a prisão civil.

Os Ministros Carlos Velloso, Marco Aurélio e Sepúlveda Pertence se mantiveram firme, por algum tempo, votando a favor da norma da Convenção Americana sobre Direitos Humanos, ou seja, deferindo habeas corpus impetrados em favor de pacientes depositários infiéis, bem como os devedores a eles equiparados legalmente, como é o caso do devedor em alienação fiduciária.

Em alguns julgados, mesmo contra a posição majoritária que vinha se estabelecendo, a corrente minoritária acabou vencedora, tendo sido o HC deferido, como se observa na decisão do HC 74383 / MG, de 22 de outubro de 1996.

\author{
HC 74383/MG \\ Relator: Ministro Néri da Silveira \\ Data do julgamento: 22/10/1996 \\ Órgão julgador: Segunda Turma
}

EMENTA.

COMPETÊNCIA - HABEAS-CORPUS - ATO DE TRIBUNAL DE ALÇADA CRIMINAL. Na dicção da ilustrada maioria, em relação à qual guardo reservas, compete ao Supremo Tribunal Federal julgar todo e qualquer habeas-corpus dirigido contra ato de tribunal ainda que não possua a qualificação de superior. Convicção pessoal colocada em segundo plano, em face de atuação em Órgão fracionário. PRISÃO CIVIL - PENHOR RURAL. A regra constitucional é no sentido de não haver prisão civil por dívida. As exceções, compreendidas em preceito estrito e exaustivo, correm à conta do inadimplemento voluntário e inescusável de obrigação alimentícia e da figura do depositário infiel - inciso LXVII do artigo $5^{\circ}$ da Constituição Federal. Supremacia da realidade, da organicidade do Direito e glosa do aspecto formal, no que o legislador ordinário, no campo da ficção jurídica, emprestou a certos devedores inadimplentes a qualificação, de todo imprópria, de depositário infiel. PRISÃO CIVIL DÍVIDAS - SUBSISTÊNCIA LEGAL. O fato de o Brasil haver subscrito o Pacto de São José da Costa Rica, situado no mesmo patamar da legislação ordinária, resultou na derrogação desta no que extrapolava a hipótese de prisão civil por inadimplemento de prestação alimentícia. ${ }^{46}$

O resultado da votação foi empate, entretanto, se decidiu por deferir o HC.

As decisões que antes eram divergentes começaram, aos poucos, a ser unânimes, sempre no sentido de indeferir os Hábeas Corpus impetrados,

\footnotetext{
${ }^{46}$ STF, HC 74383, Relator Néri da Silveira, Brasília, 22 de outubro de 1996.
} 
como foi o caso do HC 72183 / SP, de 23 de fevereiro de 1996, cujo

Ministro relator foi Marco Aurélio.

HC 72183/SP

Relator: Ministro Marco Aurélio

Data do julgamento: 23/02/1996

Órgão julgador: Segunda Turma

EMENTA

JURISPRUDÊNCIA - SUPREMO TRIBUNAL FEDERAL - OBSERVÂNCIA. A unidade de fatos $e$ a do Direito sugerem solução idêntica para as controvérsias. Tanto quanto possível, há de prevalecer a mesma solução, buscando-se, com isso, o prestígio, a respeitabilidade do Judiciário, mediante a melhor compreensão dos jurisdicionados.A óptica mais se impõe quando, em jogo tema constitucional, constata-se a existência de pronunciamento do Pleno do Guardião Maior da Carta Política da República - o Supremo Tribunal Federal. Nova discussão da matéria, a partir de convencimento pessoal, há de fazer-se em sede própria - a revelada pelo citado Plenário. Em questão crivo monocrático ou mesmo de órgão fracionário, como é a Turma, mister se faz a ressalva, homenageando- se o precedente. PRISÃO CIVIL - REGRA - EXCEÇÕES ALIENAÇÃO FIDUCIÁRIA EM GARANTIA - VIABILIDADE. Na dicção da ilustrada maioria dos integrantes do Supremo Tribunal Federal, em relação à qual guardo reservas, dentre as exceções à regra segundo à qual não haverá prisão civil por dívida está a decorrente de relação jurídica formalizada sob a nomenclatura alienação fiduciária em garantia (precedente: habeas-corpus $\mathrm{n}^{\mathrm{o}}$ 72.131/RJ, Pleno, vencidos os Ministros Marco Aurélio - relator, Francisco Rezek, Carlos Velloso e Sepúlveda Pertence, sendo designado redator para o acórdão o Ministro Moreira Alves).

Já no julgado a seguir, é possível observar outro Ministro mudando seu voto para acompanhar a corrente majoritária. Além disso, esta decisão serve de exemplo, pois um novo argumento é apresentado.

\author{
HC 79870 / SP - SÃO PAULO \\ Relator: Ministro Moreira Alves \\ Data do julgamento: $16 / 05 / 2000$ \\ Órgão julgador: Primeira Turma
}

EMENTA: Habeas corpus.

- Esta Corte, por seu Plenário (HC 72.131), já firmou o entendimento de que, em face da Carta Magna de 1988, persiste a constitucionalidade da prisão civil do depositário infiel em se tratando de alienação fiduciária, bem como que o Pacto de São José da Costa Rica, além de não poder contrapor-se ao disposto no artigo $5^{\circ}$, LXVII, da mesma Constituição, não derrogou, por ser norma infraconstitucional geral, as normas infraconstitucionais especiais sobre prisão civil do depositário infiel.

- A essas considerações, acrescenta-se outro fundamento de ordem constitucional para afastar a pretendida derrogação do Decreto-Lei no $911 / 69$ pela interpretação dada ao artigo $7^{\circ}$, item $7^{\circ}$, desse Pacto. Se se entender que esse dispositivo, que é norma infraconstitucional, revogou, tacitamente, a legislação também infraconstitucional interna relativa à prisão civil do depositário infiel em caso de 
depósito convencional ou legal, essa interpretação advirá do entendimento, que é inconstitucional, de que a legislação infraconstitucional pode afastar exceções impostas diretamente pela Constituição, independentemente de lei que permita impô-las quando ocorrer inadimplemento de obrigação alimentar ou infidelidade de depositário.

Habeas corpus indeferido. ${ }^{47}$

O Ministro Moreira Alves acrescenta um novo argumento ao debate, fortalecendo, ainda mais, a corrente majoritária. Neste sentido, afirma que o artigo $7^{\circ}$, inciso 7 do Pacto de San José da Costa Rica ingressou no ordenamento jurídico brasileiro como norma infraconstitucional. Não é possível uma norma infraconstitucional afastar a aplicação de norma constitucional. $\mathrm{O}$ artigo $5^{\circ}$, LXVII da Constituição Federal, na ressalva feita, dispõe que haverá prisão civil do depositário infiel e do devedor de obrigação alimentícia, independentemente de norma infraconstitucional que as regule.

Já o Ministro Sepúlveda Pertence, que vinha votando pela impossibilidade da prisão civil, salvo nos casos de inadimplemento de obrigação alimentícia, se uniu à jurisprudência majoritária do Tribunal, mesmo entendendo o contrário. Isso pode ser constatado claramente na ementa do acórdão em que foi relator.

RE 299627 / MG

Relator: Ministro Sepúlveda Pertence

Data do julgamento: 05/03/2002

Órgão julgador: Primeira Turma

EMENTA: Prisão civil de depositário infiel (CF, art. $5^{\circ}$, LXVII): validade da que atinge devedor fiduciante, vencido em ação de depósito, que não entregou o bem objeto de alienação fiduciária em garantia: jurisprudência reafirmada pelo Plenário do STF - mesmo na vigência do Pacto de São José da Costa Rica (HC 72.131, 22.11.95, e RE 206.482, 27.5.98) - à qual se rende, com ressalva, o relator, convicto da sua inconformidade com a Constituição.

Neste julgado, a Turma conheceu, de forma unânime, do recurso extraordinário e lhe deu provimento. ${ }^{48}$

\footnotetext{
${ }^{47}$ STF, HC 79870, Relator Moreira Alves, Brasília, 16 de maio de 2006.

${ }^{48} \mathrm{O}$ recurso extraordinário em análise foi proposto contra acórdão do Tribunal de alçada de Minas Gerais que não admitiu a prisão civil do devedor fiduciante.
} 
Consolidado este entendimento majoritário do Supremo Tribunal Federal, é possível observar a existência de dezenas de julgados que invocam o HC 72.131 e o RE 206.482.

A possibilidade da prisão civil do depositário infiel está sendo novamente debatida no Plenário do Supremo Tribunal Federal no Recurso Extraordinário n. ${ }^{\circ} 466.343$ / SP, que tem como relator o Ministro Cezar Peluso. O julgamento foi iniciado em 22 de novembro de 2006 e já conta com oito votos, maioria do Tribunal, a favor da impossibilidade da prisão do depositário infiel, bem como do alienante fiduciário.

O recurso foi interposto, com base no artigo 102, III, "a" da Constituição Federal, pelo Banco Bradesco S.A., contra acórdão do Tribunal de Justiça do Estado de São Paulo, que decidiu pela inconstitucionalidade da prisão do devedor fiduciante, face o artigo $5^{\circ}$, LXVII da Constituição Federal. Neste sentido, negaram provimento ao RE n. ${ }^{\circ} 466.343$ os Ministros Cezar Peluso, Gilmar Mendes, Ricardo Lewandowski, Joaquim Barbosa, Carlos Britto e Marco Aurélio, Celso de Mello e a Ministra Cármen Lúcia.

Merece destaque o voto do Ministro Gilmar Mendes, que será analisado mais detalhadamente. Ele divide seu voto em duas partes principais: prisão civil do depositário infiel em face dos tratados internacionais de direitos humanos; prisão civil do devedor-fiduciante em face do princípio da proporcionalidade. Apenas o primeiro tópico será fruto de análise no presente trabalho.

Sobre o status normativo adquirido pelos tratados internacionais de direitos humanos, Gilmar Mendes divide doutrina e jurisprudência em quatro correntes principais, atribuindo a tratados e convenções dessa espécie:
a) natureza supraconstitucional;
b) status de norma constitucional;
c) força de lei ordinária, estando no mesmo patamar hierárquico; e
d) caráter supralegal. 
A primeira corrente tem como defensor Celso de Albuquerque Mello. Afirma o Ministro que essa vertente não pode ser adequada a países que são regidos por princípios como o da supremacia formal e material da Constituição Federal sobre o ordenamento jurídico como um todo, como é o caso do Brasil ${ }^{49}$. Ao adotar esta corrente, se impossibilitaria o controle de constitucionalidade dos tratados internacionais que versem sobre direitos humanos. Além disso, “os tratados e convenções devem ser celebrados em consonância não só com o procedimento formal descrito na Constituição, mas com respeito ao seu conteúdo material". 50

Já a segunda corrente, que defende que os tratados e convenções de direitos humanos têm natureza constitucional, respalda sua tese no artigo $5^{\circ}, \S 2^{\circ}$ da Constituição Federal. Corrente seguida por Flávia Piovesan e Cançado Tindade que defendem que, conforme já visto no capítulo 1, as normas internacionais de direitos humanos têm um caráter especial, merecendo tratamento diferente das normas decorrentes dos demais tratados. Neste sentido, com base no artigo, $5^{\circ}, \S \S 1^{\circ}$ e $2^{\circ}$ da Constituição, que, além de atribuir a tratados e convenções sobre direitos humanos status de norma constitucional, asseguraria a eles aplicação imediata a partir da ratificação. Havendo conflito entre a norma internacional e o ordenamento jurídico interno, prevaleceria a norma mais favorável à vítima. Contra essa vertente, Gilmar Mendes afirma que com a inclusão do parágrafo $3^{\circ}$ ao artigo $5^{\circ}$ da Constituição Federal, pela Emenda 45/2004, os argumentos dos defensores desta tese teriam sido esvaziados. ${ }^{51}$ Desta forma, apenas os tratados que fossem submetidos à votação exigida no artigo $5^{\circ}, \S$ da Carta Magna podem adquirir status de norma constitucional, não tendo aqueles ratificados antes da Emenda 45/2004 este tratamento. Porém,

não se pode negar, por outro lado, que a reforma também acabou por ressaltar o Carter especial dos tratados de direitos humanos em relação aos demais tratados de reciprocidade entre os Estados pactuantes, conferindo-lhes lugar privilegiado no ordenamento jurídico. ${ }^{52}$

\footnotetext{
${ }^{49}$ STF, RE 466343, Relator Cezar Peluso, Brasília, 22 de novembro de 2006. p. 5.

${ }^{50}$ STF, RE 466343, Relator Cezar Peluso, Brasília, 22 de novembro de 2006. p. 5.

${ }^{51}$ STF, RE 466343, Relator Cezar Peluso, Brasília, 22 de novembro de 2006. p. 10.

52 STF, RE 466343, Relator Cezar Peluso, Brasília, 22 de novembro de 2006. p. 11.
} 
Com relação a terceira corrente, que coloca os tratados internacionais de qualquer espécie e as leis ordinárias em um mesmo patamar hierárquico, afirma o Ministro Gilmar Mendes ter o Supremo Tribunal Federal a adotado a partir do julgamento do RE n. ${ }^{\circ}$ 80004/SE, de 01 de junho de 1977. Havendo conflito entre a norma de direito internacional e a de direito interno, já que elas teriam o mesmo grau hierárquico, a mais recente derrogaria a mais antiga. O STF voltou a analisar o assunto, em 1995, no $\mathrm{HC} 72.131 / \mathrm{RJ}$, bem como no RE 206482/SP e em outros julgados, mantendo a posição de que os tratados internacionais têm natureza de lei ordinária. Lembra, entretanto, tendo sido o Pacto de San da Costa Rica considerado norma geral no que diz respeito a prisão do depositário infiel, ele não teria força para revogar lei especial, como o Decreto-Lei 911/69. Esta posição adotada pelo STF, conforme já visto, vem sido aplicada com freqüência nas decisões dadas por este Tribunal.

É preciso ponderar, no entanto, se, no contexto atual, em que se pode observar a abertura cada vez maior do Estado constitucional a ordens jurídicas supranacionais de proteção de direitos humanos, essa jurisprudência não teria se tornado completamente defasada. ${ }^{53}$

Gilmar Mendes afirma ainda que

a tese da legalidade ordinária, na medida em que permite ao Estado brasileiro, ao fim e ao cabo, o descumprimento unilateral de um acordo internacional, vai de encontro aos princípios internacionais fixados pela Convenção de Viena sobre o Direito dos Tratados, de 1969, a qual, em seu art. 27, determina que nenhum Estado pactuante "pode invocar as disposições de seu direito interno para justificar o inadimplemento de um tratado. ${ }^{54}$

O Ministro se filia à quarta e última corrente, que defende a supralegalidade dos tratados internacionais sobre direitos humanos. Devido ao seu caráter especial, eles não poderiam ser equiparados a leis ordinárias, contudo, não possuem status de normas constitucionais, ou seja, ocupariam um patamar hierárquico intermediário, entre a Constituição Federal e as demais legislações infraconstitucionais.

\footnotetext{
${ }^{53}$ STF, RE 466343, Relator Cezar Peluso, Brasília, 22 de novembro de 2006. p. 14.

${ }^{54}$ STF, RE 466343, Relator Cezar Peluso, Brasília, 22 de novembro de 2006. p. 21.
} 
Como exemplos, no Direito Comparado, de Constituições que adotaram esta vertente, é possível citar a Constituição da Alemanha ${ }^{55}$, a da França $^{56}$ e a da Grécia ${ }^{57}$.

Nesse sentido, é possível concluir que, diante da supremacia da Constituição sobre os atos normativos internacionais, a previsão constitucional da prisão civil do depositário infiel (art. $5^{\circ}$, inciso LXVII) não foi revogada pela ratificação do Pacto Internacional dos Direitos Civis e Políticos (art. 11) e da Convenção Americana sobre Direitos Humanos - Pacto de San José da Costa Rica (art. $7^{\circ}$, 7), mas deixou de ter aplicabilidade diante do efeito paralisante desses tratados em relação à legislação infraconstitucional que disciplina a matéria, incluídos o art. 1.287 do Código Civil de 1916 e o Decreto-Lei $n^{\circ} 911$, de $1^{\circ}$ de outubro de 1969.

Tendo em vista o caráter supralegal desses diplomas normativos internacionais, a legislação infraconstitucional posterior que com eles seja conflitante também tem sua eficácia paralisada. É o que ocorre, por exemplo, com o art. 652 do Novo Código Civil (Lei $n^{\circ}$ 10.406/2002), que reproduz disposição idêntica ao art. 1.287 do Código Civil de 1916. Enfim, desde a ratificação pelo Brasil, no ano de 1992, do Pacto Internacional dos Direitos Civis e Políticos (art. 11) e da Convenção Americana sobre Direitos Humanos - Pacto de San José da Costa Rica (art. $7^{\circ}, 7$ ), não há base legal para aplicação da parte final do art. $5^{\circ}$, inciso LXVII, da Constituição, ou seja, para a prisão civil do depositário infiel.

De qualquer forma, o legislador constitucional não fica impedido de submeter o Pacto Internacional dos Direitos Civis e Políticos e a Convenção Americana sobre Direitos Humanos - Pacto de San José da Costa Rica, além de outros tratados de direitos humanos, ao procedimento especial de aprovação previsto no art. $5^{\circ}, \S 3^{\circ}$, da Constituição, tal como definido pela EC n ${ }^{\circ} 45 / 2004$, conferindo-lhes status de emenda constitucional. ${ }^{58}$

Com base nesta argumentação, o Ministro Gilmar Mendes vota no sentido de negar provimento ao recurso.

O RE n. ${ }^{\circ} 466.343$ / SP, mesmo ainda não tem sido concluído, já é citado em outros julgados do Supremo Tribunal Federal, como no HC 90172/SP, de 05 de junho de 2007, cujo relator é o próprio Ministro Gilmar Mendes. A turma, por decisão unânime, deu provimento ao HC impetrado para evitar a prisão civil do depositário infiel.

\footnotetext{
${ }^{55}$ Art. 25 - as normas gerais do Direito Internacional Público constituem parte integrante do direito federal. Elas prevalecem sobre as leis e produzem diretamente direitos e deveres para os habitantes do território nacional

${ }^{56}$ Art. 55 da Constituição da França de 1958: "Les traités ou accords régulièrement ratifiés ou approuvés ont, dès leur publication, une autorité supérieure à celle des lois, sous réserve, pour chaque accord ou traité, de son application par l'autre partie."

${ }^{57}$ Art. 28 da Constituição da Grécia de 1975: "The generally recognized rules of international law and the international conventions after their ratification by law and their having been put into effect in accordance with their respective terms, shall constitute an integral part of Greek law and override any law provision to the contrary."

${ }^{58}$ STF, RE 466343, Relator Cezar Peluso, Brasília, 22 de novembro de 2006. p. 28/29.
} 


\author{
HC 90172/SP \\ Relator: Ministro Gilmar Mendes \\ Data do julgamento: 05/06/2007 \\ Órgão julgador: Segunda Turma
}

EMENTA: Habeas Corpus.

1. No caso concreto foi ajuizada ação de execução sob o $n^{\circ} 612 / 2000$ perante a $3^{\mathrm{a}}$ Vara Cível de Santa Bárbara D'Oeste/SP em face do paciente. A credora requereu a entrega total dos bens sob pena de prisão.

2. A defesa alega a existência de constrangimento ilegal em face da iminência de expedição de mandado de prisão em desfavor do paciente. Ademais, a inicial sustenta a ilegitimidade constitucional da prisão civil por dívida.

3. Reiterados alguns dos argumentos expendidos em meu voto, proferido em sessão do Plenário de 22.11.2006, no RE $\mathrm{n}^{\circ}$ 466.343/SP: a legitimidade da prisão civil do depositário infiel, ressalvada a hipótese excepcional do devedor de alimentos, está em plena discussão no Plenário deste Supremo Tribunal Federal. No julgamento do RE $n^{\circ}$ 466.343/SP, Rel. Min. Cezar Peluso, que se iniciou na sessão de 22.11.2006, esta Corte, por maioria que já conta com sete votos, acenou para a possibilidade do reconhecimento da inconstitucionalidade da prisão civil do alienante fiduciário e do depositário infiel.

4. Superação da Súmula $n^{\circ}$ 691/STF em face da configuração de patente constrangimento ilegal, com deferimento do pedido de medida liminar, em ordem a assegurar, ao paciente, o direito de permanecer em liberdade até a apreciação do mérito do $\mathrm{HC}^{\circ}{ }^{\circ}$ 68.584/SP pelo Superior Tribunal de Justiça. 5. Considerada a plausibilidade da orientação que está a se firmar perante o Plenário deste STF - a qual já conta com 7 votos - ordem deferida para que sejam mantidos os efeitos da medida liminar.

Neste contexto, se observa uma mudança de grande importância no Supremo Tribunal Federal, abandonando um pensamento, de um certo modo, conservador e caminhando para uma posição de primazia dos direitos e garantias fundamentais, dando maior valor ao ser humano. Além disso, frente a globalização se observa uma necessidade de abertura do ordenamento jurídico interno para o ingresso de normas internacionais.

Será abordada, a seguir, a forma como o Superior Tribunal de Justiça vem decidindo acerca da possibilidade de se decretar a prisão do depositário infiel e a conseqüente aplicação do Pacto de San José da Costa Rica à matéria.

\title{
2.2 - $O$ entendimento do Superior Tribunal de Justiça
}

O Superior Tribunal de Justiça, após a promulgação dos pactos de direitos humanos em 1992, começou a aplicá-los em diversas decisões 
envolvendo a prisão civil por dívida. É possível observar, entretanto, durante um certo tempo, uma constante mudança de argumentos por parte desse Tribunal para dar cumprimento aos tratados de direitos humanos.

No HC 3545/DF, de 10 de novembro de 1995, a Sexta Turma, de forma unânime, concedeu o habeas corpus ao devedor de alienação fiduciária em garantia sob o argumento de que

a Constituição Federal prevê a prisão civil por dívida em apenas dois casos: inadimplemento voluntário e inescusável de obrigação alimentícia e depositário infiel (art. $\left.5^{\circ}, \mathrm{LXVII}\right)$. No parágrafo $2^{\circ}$. desse mesmo art. $5^{\circ}$, está dito que 'os direitos e garantias expressos nesta Constituição não excluem outros decorrentes do regime e dos princípios por ela adotados, ou dos tratados internacionais em que a república federativa do Brasil seja parte'. Em 1991, foi incorporado em nosso ordenamento constitucional, pelo decreto legislativo $\mathrm{n}^{\circ}$. 226, de 12.12.91, textos do pacto internacional sobre direitos civis e políticos, que em seu art. 11 veda taxativamente a prisão civil por descumprimento de obrigação contratual. ${ }^{59}$

Este caso foi apreciado antes dos "leadings cases" do $\mathrm{STF}^{60}$ e o argumento dado nele questionava a aplicabilidade do artigo $5^{\circ}$, LXVII da Constituição Federal, que confronta as normas internacionais que vedavam a prisão civil por dívida. Após o julgamento do HC 72.131 / RJ, de 23 de novembro de 1995, e do RE 206482, de 27 de maio de 1998, que serviram de precedentes para diversos casos decididos no STF, o STJ passou a adotar um outro argumento. Neste sentido, deixou-se de contestar a aplicabilidade do artigo da Constituição Federal para se questionar a validade do artigo 1287 do Código Civil de 1916, que conflitava com os artigos 11 do Pacto Internacional sobre direitos civis e políticos e com o artigo $7^{\circ}$, inciso $7 \mathrm{da}$ Convenção Americana sobre Direitos Humanos.

O REsp 198191/MG, de 04 de março de 1999, expõe essa nova linha de abordagem do tema.

REsp 198191 / MG

Relator: Ministro Ruy Rosado de Aguiar

Órgão Julgador: Quarta Turma

Data do julgamento: 04/03/1999

EMENTA

ALIENAÇÃO FIDUCIÁRIA. Prisão civil. Não cabe a prisão civil do devedor fiduciante como depositário infiel. O Pacto de São José da Costa Rica, aprovado

\footnotetext{
${ }^{59}$ STJ, HC 3545, Relator Adhemar Maciel, Brasília, 10 de novembro de 1995.

${ }^{60} \mathrm{STF}, \mathrm{HC}$ 72131, Relator Marco Aurélio, Brasília, 23 de novembro de 1995.
} 
pelo Brasil e introduzido no nosso ordenamento no nível de eficácia da lei ordinária, revogou a norma geral do art. 1287 do Código Civil, que previa a prisão do depositário infiel ${ }^{61}$.

\section{Segundo Ruy Rosado de Aguiar,}

o eg. Superior Tribunal Federal 'firmou entendimento de que, em face da Carta Magna de 1988, persiste a constitucionalidade da prisão civil do depositário infiel em se tratando de alienação fiduciária, bem como que o Pacto de São Jose da Costa Rica, além de não poder contrapor-se à permissão do art 5, LXVII da mesma Constituição, não derrogou, por ser norma infraconstitucional geral, as normas infraconstitucionais especiais sobre prisão civil do depositário infiel'(HC 75306/RJ, 1 Turma, 12.09.97, rel. em. Ministro Moreira Alves).

No plano exclusivamente infraconstitucional, observa-se que a norma geral sobre prisão do depositário está no art. 1287 do CCivil, que permite compelir o depositário a restituir o bem, sob pena de prisão não excedente a um ano; o procedimento para sua decretação esta nos arts. 902 e 904 do CPC, sobre a ação de depósito. A lei especial sobre alienação fiduciária (Lei n. ${ }^{\circ}$ 4728/65, art 66, e Decreto-Lei n. ${ }^{\circ} 911 / 69$ ) não contém norma específica sobre a prisão do devedor, fazendo remissão ao Código de Processo Civil, regra de procedimento, que por sua vez regulou o modo de o juiz decretar a prisão do depositário prevista na regra geral do art 1287 do CCivil. O tratado internacional aprovado e promulgado no Brasil, tendo eficácia de lei ordinária, pode revogar a lei geral. No caso, o tratado revogou a regra geral do Código Civil, retirando o suporte a que fez remissão a lei específica (Decreto-Lei n. ${ }^{\circ}$ 911/69). Daí se conclui que no plano da legislação ordinária, a norma vigorante sobre prisão civil é o disposto no Pacto de São José, pois que, embora permitida constitucionalmente a prisão do depositário infiel, diante da norma permissiva do texto de 1988, a regra geral que a instituiu no país (art 1287 do CC) ficou derrogada pelo novo diploma (tratado aprovado), da mesma hierarquia no elenco das leis. [...] Entendimento também sustentado por Paulo Restiffe Neto e Paulo Sergio Restiffe no artigo "Prisão civil do depositário infiel em face da derrogação do art 1287 do Código Civil pelo Pacto de São Jose da Costa Rica, Revista dos Tribunais, v. 756, p $37 .{ }^{62}$

Este também foi o posicionamento da Terceira Turma do STJ, que por unanimidade não reconheceu do Recurso Especial 238372/RS, de 21 de março de 2000, afirmando que "a incorporação a nosso ordenamento jurídico das disposições constantes do Pacto de San José de Costa Rica elimina a possibilidade de prisão civil, tratando-se de alienação fiduciária 63". Os Ministros defenderam que não haveria conflito entre a norma constitucional e o Pacto, já que o artigo $5^{\circ}$, LXVII da CF não impõe a prisão civil e sim abre ao legislador ordinário, com a ressalva feita na segunda parte da norma, a possibilidade de dispor sobre a prisão civil nos

\footnotetext{
${ }^{61}$ STJ, REsp 198191, Relator Ruy Rosado Aguiar, Brasília, 04 de março de 1999.

${ }^{62}$ STJ, REsp 198191, Relator Ruy Rosado Aguiar, Brasília, 04 de março de 1999.

${ }^{63}$ STJ, REsp 238372, Relator Eduardo Ribeiro, Brasília, 21 de março de 2000.
} 
casos do depositário infiel e do inadimplente de obrigações alimentícia. Desta forma, a Convenção Americana sobre Direitos Humanos tem caráter geral absoluto, devendo ser aplicada a todos os casos, tendo ainda revogado qualquer disposição infraconstitucional que a contrarie.

Observa-se que essa linha de argumentação adotada pelo STJ após o julgamento dos "leading cases" do STF, conforme já dito, mudou o enfoque da discussão: deixou de tratar do conflito entre norma constitucional e tratado internacional ${ }^{64}$ para abordar o conflito entra norma infraconstitucional e tratado internacional. Vale destacar que o Superior Tribunal de Justiça, mesmo tendo mudado a justificativa, não mudou sua posição. Manteve-se a favor da prevalência do Pacto de San José da Costa Rica e Pacto Internacional sobre direitos civis e políticos.

O Superior Tribunal de Justiça, se apoiando na corrente monista consagrada no RE 80004/78, fundamentou suas decisões afirmando que a lei posterior derroga lei anterior que a contrarie. O Pacto de San José da Costa Rica, bem como o Pacto Internacional sobre direitos civis e políticos, passaram a produzir efeitos no território brasileiro em 1992 e estão no mesmo patamar hierárquico do Código Civil de 1916 e do Decreto-Lei 911/69. Sendo estes tratados internacionais mais recentes, devem prevalecer sobre os dispositivos mais antigos que regulavam a prisão civil do depositário infiel e dos devedores a ele equiparado legalmente. Neste sentido, a vontade mais recente do Congresso Nacional seria no sentido de não se permitir a prisão civil por dívida, salvo nos casos de inadimplemento de pensão alimentícia.

Observa-se que o Superior Tribunal de Justiça vinha se posicionando de forma contrária ao entendimento pacificado do Supremo Tribunal Federal. Como conseqüência disso, os julgados do STJ sofriam modificação pelo STF, que passavam a conhecer dos julgados por meio de interposição de recursos.

\footnotetext{
${ }^{64}$ Este conflito já estava pacificado no STF em favor da Constituição Federal.
} 
A título de exemplo, o Ministro Castro Filho da Terceira Turma do STJ, relator do RHC 11624/PB, de 27 de agosto de 2001, cita em seu voto o Recurso Extraordinário 206482/SP, interposto contra decisão do STJ, reconheceu a constitucionalidade da prisão civil do depositário infiel e, conseqüentemente, do devedor nos casos de alienação fiduciária em garantia. O Ministro Castro Filho defende que "o conveniente seria que harmônicas fossem as decisões dos dois órgãos, evitando que aos jurisdicionados se encaminhasse divergentes interpretações quanto à mesma norma legal" ${ }^{\text {65 }}$. Apesar de sua opinião, vota na mesma posição que o STJ vinha adotando.

Partindo dessa premissa levantada pelo Ministro, passou-se a adotar no STJ a posição que havia sido pacificada no STF.

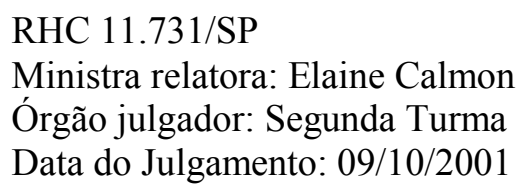

1. Doutrina e jurisprudência têm entendimento de que, do confronto entre a norma constitucional e previsão de tratado ou convenção internacionais, deve prevalecer a constituição.

2. Supremacia da norma constitucional que permite a prisão civil sobre o pacto de São José que repudia a constrição.

3. Alegações fáticas que não autorizam a exclusão de culpa.

4. Recurso improvido

Neste julgado, a Ministra Relatora ainda defende que a norma constitucional não depende de regulamentação, tendo força cogente.

Além disso, com a promulgação do Código Civil de 2002, de 10 de janeiro de 2002, o argumento de que a o Pacto de San José da Costa Rica prevaleceria sobre o Código Civil de 1916 e sobre o Decreto-Lei 911/69 se esvazia. A edição do Novo Código Civil, que ocupa o mesmo patamar hierárquico do Pacto de San José da Costa Rica e Pacto Internacional sobre direitos civis e políticos, restabeleceu a prisão civil do depositário infiel, em seu artigo 652.

\footnotetext{
${ }^{65}$ STJ, RHC 11624, Relator Castro Filho, Brasília, 27 de agosto de 2001.
} 
A partir daí, o STJ consolidou sua posição no sentido de que o Pacto de San José da Costa Rica não excluiu a possibilidade de prisão civil do depositário infiel.

HC 47.321 - PR

Relator: Ministro Luiz Fux

Órgão julgador: Primeira Turma

Data do julgamento: 15/12/2005

EMENTA

CONSTITUCIONAL. HABEAS CORPUS PREVENTIVO. SUBSTITUTIVO

DE RECURSO ORDINÁRIO. PEDIDO DE MEDIDA LIMINAR. PRISÃO CIVIL. DEPOSITÁRIO INFIEL. PACTO DE SÃO JOSÉ DA COSTA RICA. PREVALÊNCIA DA CONSTITUIÇÃO FEDERAL.

1. A prisão civil do depositário infiel, por tempo não superior a um ano, encontra amparo no artigo $5^{\circ}$, inciso LXVII, da Constituição da República, com vista a compelir o depositário infiel a cumprir sua obrigação, previsão que também resta contemplada no novel Código Civil Brasileiro (artigo 652, C. Civil).

2. É assente no Supremo Tribunal Federal que a ratificação pelo Brasil, da Convenção Americana sobre Direitos Humanos e do Pacto de São José da Costa Rica, não revogou a possibilidade de se decretar a prisão civil do depositário infiel (RE 345345, Rel. Min. Sepúlveda Pertence, DJ de 11/04/2003;RE 344585, Rel. Min. Moreira Alves, DJ de 13/09/2002).

3. A prisão do depositário infiel, conforme jurisprudência compendiada na Súmula n. ${ }^{\circ} 619$ do Supremo Tribunal Federal, "pode ser decretada no próprio processo em que se constitui o encargo, independentemente da propositura de ação de depósito".

$\mathrm{O}$ pedido de $\mathrm{HC}$ foi denegado, por maioria, tendo sito vencido o

Ministro José Delgado. No julgado ora analisado, o Ministro Relator defende a prisão do depositário civil e pauta seu voto em diversas decisões dadas pelo Supremo Tribunal Federal, como se observa no trecho abaixo:

com efeito, a prisão civil do depositário infiel, por tempo não superior a um ano, encontra amparo no artigo $5^{\circ}$, inciso LXVII, da Constituição da República, com vista a compelir o depositário infiel a cumprir sua obrigação, previsão que também resta contemplada no novel Código Civil Brasileiro, em seu artigo 652, verbis:

Art. 652. Seja o depósito voluntário ou necessário, o depositário que não o restituir quando exigido será compelido a fazê-lo mediante prisão não excedente a um ano, e ressarcir os prejuízos.

Como cediço, a jurisprudência do Supremo Tribunal Federal vem afirmando que a ratificação pelo Brasil, da Convenção Americana sobre Direitos Humanos e do Pacto de São José da Costa Rica, não revogou a possibilidade de se decretar a prisão civil do depositário infiel. ${ }^{66}$

\footnotetext{
${ }^{66}$ STJ, HC 47321, Relator Luiz Fux, Brasília, 15 de dezembro de 2005.
} 
Observa-se, que mesmo depois do voto proferido pelo Ministro do Supremo Tribunal Federal, Gilmar Mendes, no RE 466343/SP, de 22 de novembro de 2006, o STJ continua votando pela impossibilidade de aplicação do Pacto de San José da Costa Rica. O RE 466.343 indica uma mudança na linha decisória do STF. Porém, o STJ, em julgados recentes, tem fundamentado suas decisões em antigos julgados do Supremo Tribunal Federal, como é o caso do REsp 967649, de 18 de outubro de 2007.

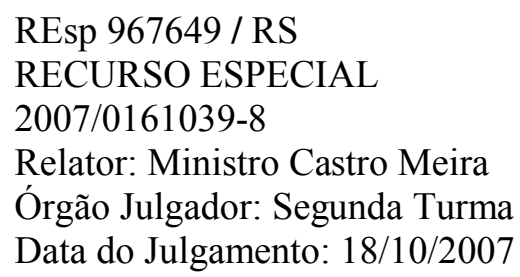

EMENTA

PROCESSUAL CIVIL. EXECUÇÃO FISCAL DEPOSITÁRIO INFIEL. PRISÃO CIVIL. INAPLICAÇÃO DO PACTO DE SÃO JOSÉ DA COSTA RICA.

1. O Supremo Tribunal Federal vem reconhecendo que "a prisão de quem foi declarado, por decisão judicial, como depositário infiel é constitucional, seja quanto ao depósito regulamentado no Código Civil como no caso de alienação protegida pela cláusula fiduciária" (HC 73.044/SP, Rel. Min. Maurício Correia,DJU 20.09.96).

2. Constitui dever do depositário prover a guarda e a conservação do bem. A prisão civil, entretanto, somente se justifica quando há recusa do depositário de restituir o bem que está sob sua custódia.

3. Inaplicação da Convenção Americana sobre Direitos Humanos (Pacto de São José da Costa Rica) mesmo após a edição da Emenda Constitucional no 45/04, ante a falta de aprovação pelo quorum qualificado de três quintos, o que impede, nos exatos termos da norma do art. $5^{\circ}, \S 3^{\circ}$, da $\mathrm{CF}$, que se o tenha por recepcionado pelo direito interno com status de emenda constitucional.

4. Recurso especial provido.

O Ministro Castro Meira relembra um argumento apresentado pelo Ministro Teori Albino Zavascki, da Primeira Turma, no RHC 19087, de 18 de maio de 2006.

RHC 19087 / MG

RECURSO ORDINARIO EM HABEAS CORPUS

2006/0034337-2

Relator: Ministro Teori Albino Zavascki

Órgão Julgador: Primeira Turma

Data do julgamento: 18/05/2006

EMENTA

CONSTITUCIONAL. HABEAS CORPUS. PRISÃO CIVIL DE DEPOSITÁRIO INFIEL. POSSIBILIDADE, MESMO APÓS O ADVENTO DA EC 45/2004, QUE INTRODUZIU O $\S 3^{\circ}$ NO ART. $5^{\circ}$ DA CONSTITUIÇÃO FEDERAL. 
PENHORA EM EXECUÇÃO FISCAL. FALÊNCIA SUPERVENIENTE. SÚMULA 305/STJ. NÃO INCIDENTE NA HIPÓTESE DOS AUTOS.

1. Nos termos do $\S 3^{\circ}$ do art. $5^{\circ}$ da CF (introduzido pela EC 45/2004), "Os tratados e convenções internacionais sobre direitos humanos que forem aprovados, em cada Casa do Congresso Nacional, em dois turnos, por três quintos dos votos dos respectivos membros, serão equivalentes às emendas constitucionais". Trata-se de exceção à regra geral segundo a qual os tratados internacionais ratificados pelo Brasil incorporam-se ao direito interno como lei ordinária.

2. Quanto aos tratados sobre direitos humanos preexistentes à EC 45/2004, a transformação da sua força normativa - de ordinária para constitucional - também supõe a observância do requisito formal de ratificação pelas Casas do Congresso, por quorum qualificado de três quintos. Tal requisito não foi atendido, até a presente data, em relação ao Pacto de São José da Costa Rica (Convenção Americana de Direitos Humanos). Continua prevalecendo, por isso, o art. $5^{\circ}$, LXVII, da Constituição Federal, que autoriza a prisão civil do depositário infiel. 3. É cabível a prisão civil de depositário infiel de bens penhorados em execução fiscal.

4. A aplicação da Súmula 305/STJ supõe demonstração não apenas do decreto de falência, mas também da efetiva arrecadação dos bens pelo síndico. Precedentes.

5. Recurso a que se nega provimento.

Teori Albino Zavascki, em seu voto, afirma que o Pacto de San José da Costa Rica, mesmo contendo direitos fundamentais, não possui status de norma constitucional. O $\S 3^{\circ}$ do artigo $5^{\circ}$ da Constituição Federal, introduzido em nosso ordenamento jurídico pela Emenda 45/2004, abre uma possibilidade para que os tratados de direitos humanos adquiram status constitucional. Isso, entretanto, não significa que "há novação automática dos tratados de força normativa"67 já ratificados. Para que eles adquiram posição de norma constitucional, tem que ser submetidos à nova votação. Sendo assim, afirma que se deve seguir o entendimento que o STF vinha adotando antes do RE 466343, de que a prisão do depositário infiel não foi revogada pelo Pacto de San José da Costa Rica.

\section{3 - Comparação das posições jurisprudenciais do STF e do STJ}

O Superior Tribunal de Justiça em 1995, ou seja, logo após a promulgação do Pacto de San José da Costa Rica em 1992, decidiu por aplicá-lo em suas decisões, afastando a prisão civil do depositário infiel.

\footnotetext{
${ }^{67}$ STJ, RHC 19087, Relator Teori Albino Zavascki, Brasília, 18 de maio de 2006.
} 
Fazia isso com base no artigo $5^{\circ}, \S 2^{\circ}$ da Constituição Federal. Porém, o Supremo Tribunal Federal, na primeira oportunidade em que o Plenário pode decidir sobre a aplicação do artigo $7^{\circ}$, inciso do Pacto, no $\mathrm{HC}$ 72.131/RJ, em 23 de novembro de 1995, por maioria dos votos, prevaleceu a posição que defendia a inconstitucionalidade da referida norma internacional, tendo em vista sua contrariedade frente o artigo $5^{\circ}, \mathrm{LXVII}$ da CF. Além disso, para maior parte dos Ministros do STF, o Pacto de San José da Costa Rica, por ser norma de caráter geral, não teria força para revogar o Decreto-Lei 911/69. No mesmo sentido desse julgado, temos o RE 206482/SP, de 27 de maio de 1998, ficando ambos como "leading cases” da posição do STF.

Com o estabelecimento de precedente da posição vencedora do STF, o argumento do STJ utilizado para a aplicação do Pacto de San José da Costa Rica não se sustentava mais, pois havia sido fortemente combatido pelo Supremo. Neste sentido, o STJ mudou seu argumento. Deixou de questionar o conflito entre o Pacto e a Constituição, no qual o STF já tinha estabelecido a primazia da Carta Magna, para atacar as demais legislações ordinárias que contrariavam o Pacto.

O REsp 198191/MG, de 04 de março de 1999, expõe essa nova linha de abordagem do tema, afirmando que tanto o artigo 1287 do Código Civil de 1916 como os artigos 902 e 904 do CPC foram derrogados pelas normas internacionais ratificadas pelo Brasil, deixando o Decreto-Lei 911/69 sem suporte. Observa-se que o SJT vinha decidindo no sentido de que a lei mais recente, no caso o Pacto de San José da Costa Rica, deveria prevalecer. Porém, bastava que uma lei fosse promulgada para que este argumento ficasse sem fundamento.

O STF, contudo, mantinha forte sua posição em não reconhecer que o Pacto de San José deveria ser aplicado a questões envolvendo a prisão do depositário infiel, bem como a dos devedores a ele legalmente equiparados. Conseqüência disso é que todas as decisões em que o STJ dava prioridade a aplicação da legislação internacional, quando recorridas e julgadas pelo 
STF, acabavam sendo reformadas. Essa interpretação divergente entre os dois Tribunais criava uma certa instabilidade, o que levou, em 2001, o STJ a mudar drasticamente sua posição e a decidir da mesma forma que o STF vinha fazendo. Observa-se que naquele momento ambos adotaram uma posição conservadora, se fechando para a aplicação das normas internacionais.

O RE 466343, de 22 de novembro de 2006, que está sendo julgado no STF, apresenta uma nova abordagem do tema, conforme visto anteriormente. $\mathrm{O}$ voto do Ministro do Gilmar Mendes levanta uma visão a favor do tratamento especial que se deve dar às normas internacionais de direitos humanos. Neste sentido, a teoria fundamentada por ele parece ser a que melhor soluciona o conflito que se mantém desde a promulgação do Pacto de San José da Costa Rica, levando em consideração os argumentos por ele mesmo apresentados.

Contrariamente, o STJ, em julgados mais recentes, continua negando a aplicação do Pacto e fundamenta suas decisões na posição antiga dos "leading cases" do STF. Observa-se uma adesão tardia do STJ a vertente que já vem sendo adotada pelo STF desde 1995. Com a mudança na forma de solucionar o conflito, proposta por Gilmar Mendes, nem mesmo o STF se mantém tão preso a sua antiga opinião, como tem feito o STJ.

Neste sentido, se espera que com o término do julgamento do RE 466343, de 22 de novembro de 2006, a posição do Ministro Gilmar Mendes, que já conta com a maioria dos votos, passe a ser o novo "leading case", unificando os entendimentos do Supremo Tribunal Federal e Superior Tribunal de Justiça. 


\section{Conclusão}

No capítulo 1 foi apresentada a forma de ingresso dos tratados internacionais no ordenamento jurídico brasileiro. Primeiramente, foram apresentadas as teorias dualista e monista acerca do conflito entre normas de Direito Internacional e Direito Interno. Constatou-se que a legislação brasileira é lacunosa, não mostrando que norma deve prevalecer quando forem contrárias, ficando a cargo da doutrina e da jurisprudência estabelecer qual teoria melhor retrata a realidade brasileira, não sendo as posições pacíficas quanto este ponto. Com base no RE 80004/77, entretanto, firmou-se no STF o entendimento de que a norma posterior derrogaria a anterior com ela conflitante, o que leva a crer que se estaria adotando um monismo moderado.

Ainda naquele capítulo, foi feito um levantamento das correntes acerca da posição hierárquica ocupada pelos tratados internacionais dentro do ordenamento jurídico brasileiro. Neste ponto, foi analisada a posição ocupada pelo Pacto de San José da Costa Rica, bem como sua posição frente diversas normas pátrias que cuidam da prisão civil do depositário infiel. Levou-se em consideração as mudanças legislativas ao longo da época analisada: desde a ratificação do Pacto em 1992 até os dias atuais.

Já no segundo capítulo, se debateu a possibilidade de prisão do depositário infiel e a constitucionalidade do Pacto de San José da Costa Rica. Foram focadas, com maior atenção, as posições adotadas pelo Supremo Tribunal Federal e pelo Superior Tribunal de Justiça, por meio de uma análise da aplicação prática do tema nos grandes tribunais brasileiros. Assim, ficaram evidenciadas as diferentes posições e argumentos apontados pelos Ministros ao longo dos anos, bem como foi feita uma comparação dos entendimentos destes Tribunais. Mereceu destaque neste ponto o voto do Ministro Gilmar Mendes, proferido no Recurso Extraordinário n. ${ }^{\circ} 466.343$ / SP , ainda em julgamento. 
O Ministro traz uma forma de solução dos conflitos envolvendo normas de Direito Internacional e Direito Interno, defendendo a supralegalidade dos tratados internacionais de direitos humanos, destacando que eles merecem tratamento especial.

Entendo que esta saída dada pelo Ministro Gilmar Mendes parece a que melhor soluciona o problema envolvendo este tipo de conflito de normas. Além disso, à luz do que foi analisado, se espera que com o julgamento do RE em questão, o STF mude sua posição acerca da matéria e passe a votar no mesmo sentido do Ministro. A partir daí, deverá ocorrer ainda uma unificação dos entendimentos do STF e do STJ, deixando de haver discrepâncias nas decisões destes Tribunais. 


\section{Bibliografia}

ARAÚJO, Nadia de. Direito internacional privado: teoria e prática brasileira. $3^{\mathrm{a}}$ ed. Rio de Janeiro: Renovar, 2006. 604 p.

CARVALHO NETO, Inácio de. A prisão do depositário infiel, o Pacto de São José da Costa Rica e o Novo Código Civil. Disponível em http://www.mundojuridico.adv.br/cgi-bin/upload/texto639.rtf. Acesso em 10 de maio de 2008.

CASTRO, Carlos Roberto Siqueira. A Constituição aberta e os direitos fundamentais. Rio de Janeiro: Editora Forense, 2003. 813 p.

DOLINGER, Jacob. Direito Internacional Privado: parte geral. $4^{\mathrm{a}}$ ed. Rio de Janeiro: Renovar, 1996. 479 p.

KOEHLER, Frederico Augusto Leopoldino. Hierarquia dos tratados internacionais em face do ordenamento jurídico interno: um estudo sobre a jurisprudência do STF. Disponível em: http://jus2.uol.com.br/doutrina/texto.asp?id=10491 . Acesso em $10 \mathrm{de}$ maio de 2008.

LOPES, Anselmo Henrique Cordeiro. A força normativa dos tratados internacionais de direitos humanos e a Emenda Constitucional $n^{o}$ 45/2004. Disponível em http://jus2.uol.com.br/doutrina/texto.asp?id=6157 . Acesso em $10 \mathrm{de}$ maio de 2008 .

MAZZUOLI, Valério de Oliveira. Prisão civil por dívida e o Pacto de San José da Costa Rica. Rio de Janeiro: Forense, 2002. 
PIOVESAN, Flávia. Valor Jurídico dos Tratados: Impacto na Ordem Interna e Internacional. Disponível em: http://www.mundojuridico.adv.br. Acesso em 30 de abril de 2008.

.Prisão do depositário infiel: constitucionalidade. Disponível em: http://www.mundojuridico.adv.br. Acesso em 30 de abril de 2008.

RAMOS, André de Carvalho. Teoria geral dos direitos humanos na ordem internacional. Rio de Janeiro: Renovar, 2005. 302 p.

SILVA, José Afonso da. Curso de Direito Constitucional Positivo. 23ª ed. São Paulo: Malheiros Editores, 2004. 900 p.

STF, CR AgR 8279, Relator Celso de Mello, Brasília, 17 de junho de 1998.

STF, HC 72131, Relator Marco Aurélio, Brasília, 23 de novembro de 1995.

STF, HC 72183, Relator Marco Aurélio, Brasília, 23 de fevereiro de 1996.

STF, HC 73044, Relator Maurício Corrêa, Brasília, 19 de março de 1996.

STF, HC 74383, Relator Néri da Silveira, Brasília, 22 de outubro de 1996.

STF, HC 90172, Relator Gilmar Mendes, Brasília, 05 de junho de 2007.

STF, HC 79870, Relator Moreira Alves, Brasília, 16 de maio de 2006.

STF, RE 80004, Relator Xavier de Albuquerque, Brasília, 01 de junho de 1977.

STF, RE 206482, Relator Maurício Corrêa, Brasília, 27 de maio de 1998. 
STF, RE 299627, Relator Sepúlva Pertence, Brasília, 05 de março de 2002.

STF, RE 466343, Relator Cezar Peluso, Brasília, 22 de novembro de 2006.

STJ, HC 3545, Relator Adhemar Maciel, Brasília, 10 de novembro de 1995.

STJ, HC 47321, Relator Luiz Fux, Brasília, 15 de dezembro de 2005.

STJ, REsp 198191, Relator Ruy Rosado Aguiar, Brasília, 04 de março de 1999.

STJ, REsp 967649, Relator Castro Meira, Brasília, 18 de outubro de 2007.

STJ, REsp 238372, Relator Eduardo Ribeiro, Brasília, 21 de março de 2000 .

STJ, RHC 11624, Relator Castro Filho, Brasília, 27 de agosto de 2001.

STJ, RHC 11731, Relatora Elaine Calmon, Brasília, 09 de outubro de 2001.

STJ, RHC 19087, Relator Teori Albino Zavascki, Brasília, 18 de maio de 2006.

TRINDADE, Antônio Augusto Cançado. Repertório da prática brasileira do direito internacional público (período de 1919-1940). Brasília: Escopo Editora, 1984. 278 p.

TRF - $5^{\circ}$ Região, AC 238842, Relatora Margarida Cantarelli, Rio Grande do Norte, 30 de agosto de 2001. 